\title{
Estimating surface runoff and groundwater recharge in an urban catchment using a water balance approach
}

\author{
Robin K. Weatherl ${ }^{1,2,3}$ (D) Maria J. Henao Salgado ${ }^{1,4} \cdot$ Maximilian Ramgraber $^{1,2,5} \cdot$ Christian Moeck $^{1} \cdot$ Mario Schirmer $^{1,2}$
}

Received: 1 March 2021 / Accepted: 22 July 2021 / Published online: 24 August 2021

(C) The Author(s) 2021

\begin{abstract}
Land-use changes often have significant impact on the water cycle, including changing groundwater/surface-water interactions, modifying groundwater recharge zones, and increasing risk of contamination. Surface runoff in particular is significantly impacted by land cover. As surface runoff can act as a carrier for contaminants found at the surface, it is important to characterize runoff dynamics in anthropogenic environments. In this study, the relationship between surface runoff and groundwater recharge in urban areas is explored using a top-down water balance approach. Two empirical models were used to estimate runoff: (1) an updated, advanced method based on curve number, followed by (2) bivariate hydrograph separation. Modifications were added to each method in an attempt to better capture continuous soilmoisture processes and explicitly account for runoff from impervious surfaces. Differences between the resulting runoff estimates shed light on the complexity of the rainfall-runoff relationship, and highlight the importance of understanding soil-moisture dynamics and their control on hydro(geo)logical responses. These results were then used as input in a water balance to calculate groundwater recharge. Two approaches were used to assess the accuracy of these groundwater balance estimates: (1) comparison to calculations of groundwater recharge using the calibrated conceptual HBV Light model, and (2) comparison to groundwater recharge estimates from physically similar catchments in Switzerland that are found in the literature. In all cases, recharge is estimated at approximately $40-45 \%$ of annual precipitation. These conditions were found to closely echo those results from Swiss catchments of similar characteristics.
\end{abstract}

Keywords Surface runoff · Groundwater recharge · Urban groundwater · Curve number · Hydrograph separation

\section{Introduction}

Groundwater is among the most important reserves of freshwater on the planet, critical for drinking water resources as well as for healthy ecosystem functioning. Groundwater

Robin K. Weatherl

robin.weatherl@protonmail.com

1 Department of Water Resources and Drinking Water, Swiss Federal Institute of Aquatic Science and Technology (Eawag), Dübendorf, Switzerland

2 Centre for Hydrogeology and Geothermics (CHYN), University of Neuchâtel, Neuchâtel, Switzerland

3 Present address: INTERA Inc., Austin, TX, USA

4 Present address: Faculty of Engineering and Architecture, National University of Colombia, Bogotá, Colombia

5 Present address: Department of Aeronautics and Astronautics, Massachusetts Institute of Technology, Cambridge, MA, USA reserves are replenished through aquifer recharge, which is highly responsive to climate change and land development (Gurdak et al. 2007). Unconfined shallow aquifers in particular are inherently vulnerable to short-term dynamics such as precipitation excess or deficit, or to quality degradation from surface influences (Thomas et al. 2017; Vogt and Somma 2000). This vulnerability translates into increased risk of contamination in areas impacted by human land use (Burri et al. 2019; Hale et al. 2014; Jurado et al. 2014; K'oreje et al. 2016; Meyer et al. 2005; Scanlon et al. 2007; Schirmer et al. 2011; Sharp et al. 2003; Vázquez-Suñé et al. 2005). As more than $50 \%$ of the world's population is now living in cities, an increasing number of studies have been dedicated to investigating the numerous and complex changes in the water cycle in general, and groundwater recharge in particular, in urbanizing environments (Barron et al. 2013; Ficklin et al. 2010; Lerner 1990; Minnig et al. 2018; Schirmer et al. 2013; Wakode et al. 2018). Groundwater recharge is influenced by many factors; therefore, its accurate characterization requires properly 
accounting for the individual environmental variables (e.g. soil texture, land cover) and water balance components (e.g. climatic forcing functions) that contribute to its dynamics.

Surface runoff in particular is one of several important components in a groundwater recharge balance, acting as a direct link between surface flow conditions and groundwater bodies via groundwater-surface water interactions (Foster and Chilton 2004; Musolff et al. 2010). Surface runoff is defined here as the excess precipitation that flows at the land surface immediately following a storm event (Harbor 1994). Like recharge, surface runoff dynamics have been shown to be heavily altered by human activity, often in very complex ways (Eshtawi et al. 2016; Gremillion et al. 2000; Harbor 1994). Increases in the amount surface runoff are often observed in developed areas as a result of increased impervious surfaces, soil compaction, and drainage infrastructure (Eshtawi et al. 2016; Rose and Peters 2001).

As neither groundwater recharge nor surface runoff can be directly measured on large scales, both must be inferred indirectly (Foster et al. 1999; Rammal et al. 2018). This typically leads to great uncertainties in estimates, difficulties in characterizing runoff-recharge relationships in changing environments, and subsequent difficulties in effectively protecting and managing groundwater resources. Great efforts have been made to improve understanding of these dynamics, and many different approaches of varying complexity have been implemented to study rainfall routing and groundwater recharge (Scanlon et al. 2002). Examples include empirical and conceptual water balances (e.g. Bergström and Lindström 2015; Minnig et al. 2018; Wittenberg and Sivapalan 1999); thermal, chemical, or isotopic tracers (e.g. Meriano et al. 2011; Solomon et al. 1993); timeseries analyses (e.g. Bakker and Schaars 2019; Crosbie et al. 2005); statistical and numerical modeling (e.g. Bakker et al. 2016; Döll and Fiedler 2008; Moeck et al. 2017); remote sensing and Geographic Information Systems (e.g. Sheffield et al. 2018; Tweed et al. 2007), as well as combined method approaches (e.g. Brunner et al. 2004; Hornero et al. 2016; von Freyberg et al. 2015). In general, it is considered good practice to carry out estimations using multiple approaches because of the differing spatiotemporal applicability between different methods, as well as the uncertainties involved in all approaches (Crosbie et al. 2010; Healy and Cook 2002).

Surface runoff can be quantified in a number of ways, most commonly with pluviometric methods based on precipitation data, or with hydrograph methods based on river discharge data (Hernández-Guzmán and Ruiz-Luna 2013; Kirchner 2019; Rammal et al. 2018; Woldemeskel and Sharma 2016). Pluviometric methods based wholly or partially on the Natural Resources Conservation Service Curve Number equations (USDA Natural Resources Conservation Service 1986) are popular due to their suitability for small-scale applications, applicability in ungauged catchments, low data requirements, and thorough documentation and case studies in literature (Ajmal et al. 2016; Arnold et al. 2012; Hernández-Guzmán and Ruiz-Luna 2013; Minnig et al. 2018; Mishra and Singh 2003; Soulis and Valiantzas 2012; Thomas and Tellam 2006; Verma et al. 2017; Wakode et al. 2018; Wang et al. 2012; Zope et al. 2017). Modern adaptations of the method attempt to improve soil-moisture accounting (e.g. Bartlett et al. 2016; Michel et al. 2005; Mishra et al. 2003; Sahu et al. 2010; Singh et al. 2015; Wał ga and Rutkowska 2015), or to explore the proportionality concept that is of unclear origins (Hooshyar and Wang 2016).

For hydrograph methods, river discharge gives a great deal of insight into storm runoff response and changing water dynamics within a catchment. River discharge, also referred to as streamflow, is composed largely of slow-moving baseflow and the rapid-response of quickflow. A discharge hydrograph can be separated into individual components using simple recursive digital filters (Chapman 1991; Li et al. 2014; Nathan and McMahon 1990; Willems 2009), or with more sophisticated methods using high-frequency chemical or isotope composition in addition to streamflow timeseries (Jasechko et al. 2016; Lyon et al. 2012; Penna et al. 2015; Von Freyberg et al. 2017).

Groundwater recharge for shallow aquifers is often determined via "top-down" water balancing, which uses data on surface conditions in order to estimate the partitioning of precipitation between evapotranspiration, runoff, and recharge (e.g. Arnold and Allen 1999; Minnig et al. 2018; Seibert and Vis 2012). Major control factors for precipitation partitioning include climate, geology, geomorphology, precipitation intensity, and land cover, among others (Gannon et al. 2014; Moeck et al. 2020a; Stanton et al. 2013). In urban environments, water balances can be expanded to account for additional inputs such as sewer leakage, effluent, or irrigation. However, recharge estimates from these water balances are only as good as the estimates of their individual variables, and are thus contingent on identifying and accurately quantifying the significant input and output variables.

While increases in computational power have enabled the development of fully distributed, physically based numerical models, the use of empirical and conceptual models remains popular. This can be attributed to the large data requirements and consequent uncertainty in parameters that are necessary for numerical modeling, while simple methods are more widely accessible due to minimal data requirements, relatively straightforward parameterization, and simplicity in application (Bakker and Schaars 2019). Because of this fact, it is important to continually explore the performance of simplified approaches in different environments to validate their applicability. The basic data necessary for simpler methods are readily accessible on large spatial scales, due in great part to the organization of free databases provided by local governments up to global organizations such as the Center for Global Environmental Research 
(CGER) or the United Nations Food and Agriculture Organization (UN FAO). In addition, many small-scale published datasets from around the world (e.g. Crosbie et al. 2010; Moeck et al. 2020a) are also freely available.

With these ideas in mind, the objective of this study is to apply empirical and conceptual methods to quantify and explore runoff dynamics, and to assess their suitability to estimate groundwater recharge in an urbanizing environment. This is carried out in a small catchment located on the Swiss Plateau that is undergoing active transition from an agricultural landscape into an urban landscape. This catchment is of interest as the groundwater is the principal source of drinking water for the local population and is representative of the active increase in urbanization that many towns are currently undergoing. This offers a prime opportunity to observe these changes as they occur. The relative strengths and shortcomings of each of the investigated methods are discussed. With these comparisons, it is possible to gauge the ability of these straightforward methods to offer satisfactory characterization of the water cycle in a human-impacted catchment.

Two approaches were used to estimate catchment surface runoff: (1) a modified version of the NRCS-CN method, called the Sahu-Mishra-Eldho (SME) model after its authors (Sahu et al. 2010, 2012); compared to (2) an automated hydrograph separation using the popular recursive digital filter as outlined by Nathan and McMahon (1990). In this application of the SME model, additional modifications were made for soil-moisture calculations, making use of an antecedent precipitation index. For hydrograph separation, a wide range of filter parameters suited to urban environments were explored. Two approaches were then used to estimate groundwater recharge: (1) an empirical water balance using the surface runoff estimates as input, followed by (2) application of the conceptual HBV Light model (Seibert and Vis 2012). As a final step, these results were compared with recharge estimates found in the literature for similar Swiss catchments.

\section{Case study}

The upper Kempttal catchment on the Swiss Plateau is located approximately $10 \mathrm{~km}$ east of the city of Zürich, Switzerland (Fig. 1). The catchment is defined topographically from publicly available data (Swiss Federal Office of Topography), and covers an area of approximately $35 \mathrm{~km}^{2}$ with an increasing elevation from NW-SE: 520 masl at the lower outlet area (NW), and up to approximately 900 masl in the upper headwater area (SE). The catchment contains a small tributary network feeding into the Kempt River, which is modified via canalization and deepening of the river bed within the central urban municipality, Fehraltorf. Flow in the Kempt River is supplemented by wastewater effluent released near its outflow, and is conceptualized here as an integral contribution to river baseflow. Shallow geology is composed of unconsolidated fluvio-glacial sediments that are host to an unconfined aquifer (Fig. 1a). The deepest zones of the aquifer body are in the central valley and have been reported at 10 $20 \mathrm{~m}$, with thinner portions between 1 and $8 \mathrm{~m}$ on the valley edges (Krejci et al. 1994), though these estimates are uncertain. The residence time of groundwater is assumed to be relatively short, on the order of months to 2 years (Krejci et al. 1994). The aquifer provides approximately $80 \%$ of freshwater resources for local communities (Reinhardt et al. 2019).

Currently, land cover consists of 53\% agriculture, 25\% forest, and $22 \%$ urban area. Sealed surfaces and drained areas are present within both urban and agricultural areas, covering approximately $10 \%$ of the entire catchment (Fig. 1b; Federal Statistical Office of Switzerland GEOSTAT). Sealed surfaces correspond principally to roads and buildings, whereas drained areas correspond to tile drains and open ditches. Surface and underground drainage systems exist in several areas. Most storm drains are separated from the sewer network and direct runoff into the river network within the catchment via sewer inflow. However, some central areas are still served with storm-water systems combined to the sewer network, diverting runoff towards the wastewater treatment plant via sewer inflow. These combined systems can lead to combined sewer overflow (CSO) during heavy storms when network flow capacity is exceeded; additional details on the study site may be referenced in Ramgraber et al. (2021).

\section{Observation data}

Table 1 gives a summary of the principal datasets considered, all on a daily timescale. Surface-water discharge $(Q)$ was collected from a single gauging station near the outflow of the catchment, approximately $500 \mathrm{~m}$ downstream of the wastewater treatment plant for the municipality of Fehraltorf. Table 2 lists annual values of the water balance variables over the study period. For these calculations, $Q$ as well as pumping rates were converted into units of depth by dividing their values by the catchment area. As the Kempttal catchment is in fact a subcatchment of the greater Tösstal catchment, regional flow is expected from the surrounding hillslopes, such that this catchment is not a closed system (Ramgraber et al. 2021).

\section{Materials and methods}

\section{Surface runoff}

\section{SME method}

The SME method was first proposed by Sahu et al. (2010) as an improvement of the NRCS-CN method (USDA Natural 
Fig. 1 a Shallow geology of the upper Kempttal catchment. The aquifer is principally located within the glacial, loamy, and alluvial sediments of the catchment. b Sealed surfaces and drained areas in the catchment correspond to impervious surfaces in the urban area and drainage networks in agricultural areas. Public sources: Swiss Federal Office of Meteorology and Climatology (MeteoSwiss); Canton Zürich Office for Waste, Water, Energy, and Air (AWEL); Swiss Federal Office for the Environment (FOEN), Swiss Federal Office of Topography (Swisstopo)
Table 1 Summary of main databases considered in the current study

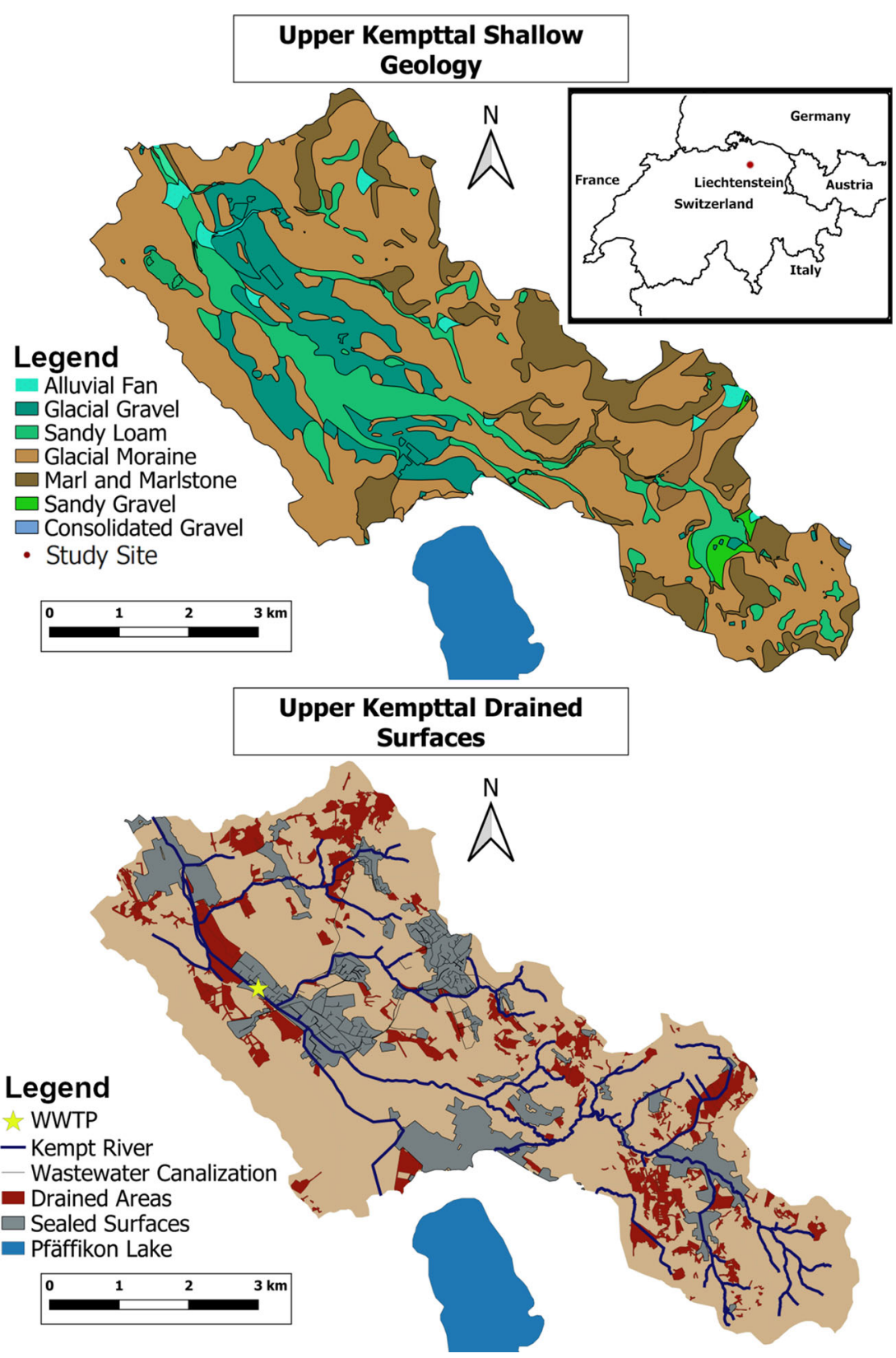

\begin{tabular}{lll}
\hline Data type & Source & Time period \\
\hline Precipitation $(P)$ & MeteoSwiss & $2007-2018$ \\
River discharge $(Q)$ & AWEL & $2007-2018$ \\
Reference Evapotranspiration $(E T)$ & MeteoSwiss & $2007-2018$ \\
Groundwater pumping & Municipality Fehraltorf & $2014-2017$ \\
Land cover & GEOSTAT; AWEL; FOEN & 2015 \\
Paved surface area & Canton Zürich & 2015 \\
\hline
\end{tabular}

Public sources: Swiss Federal Office of Meteorology and Climatology (MeteoSwiss); Canton Zürich Office for Waste, Water, Energy, and Air (AWEL); Municipality Fehraltorf; Swiss Federal Statistical Office GEOSTAT; Swiss Federal Office for the Environment (FOEN) 
Table 2 Annual sums of major water balance variables during the period of study

\begin{tabular}{lllll}
\hline Year & $P(\mathrm{~mm})$ & ET $(\mathrm{mm})$ & $Q(\mathrm{~mm})$ & GW pumping $(\mathrm{mm})$ \\
\hline 2007 & $1,137.3$ & 445.7 & 443.1 & - \\
2008 & $1,115.7$ & 422.8 & 323.7 & - \\
2009 & $1,057.5$ & 433.5 & 325.4 & - \\
2010 & $1,207.5$ & 414.8 & 462.6 & - \\
2011 & 961.1 & 514.2 & 305.7 & - \\
2012 & $1,329.5^{\mathrm{a}}$ & 450.0 & 605.9 & - \\
2013 & $1,156.6$ & 441.7 & 577.8 & - \\
2014 & $1,116.8$ & 430.4 & 531.2 & $23.7^{\mathrm{a}}$ \\
2015 & 891.6 & 554.8 & 452.0 & 32.8 \\
2016 & $1,268.4$ & $403.8^{\mathrm{b}}$ & $660.2^{\mathrm{a}}$ & 29.4 \\
2017 & $1,048.6$ & 475.6 & 438.9 & $36.5^{\mathrm{b}}$ \\
2018 & $889^{\mathrm{b}}$ & $554.9^{\mathrm{a}}$ & $288.4^{\mathrm{b}}$ & - \\
Ave. & $1,094.7$ & 462.0 & 451.3 & 30.6 \\
\hline
\end{tabular}

Precipitation is assumed to represent the maximum potential recharge, reference evapotranspiration ET is the principal precipitation loss factor, and $Q$ is streamflow, which is an integrated signal of surface runoff and groundwater exfiltration. Ave. is average

${ }^{\text {a }}$ Corresponds to the highest yearly values

${ }^{\mathrm{b}}$ Corresponds to the lowest yearly values

Data courtesy of MeteoSwiss and Municipality Fehraltorf Municipality (2018)

Resources Conservation Service 1986). A brief introduction of the NRCS-CN method and its governing equations can be found in the electronic supplementary material (ESM), with more thorough information found in Mishra and Singh (2003). The SME method is based on the same water balance as that of the original $\mathrm{CN}$ (Eq. S1 of the ESM) plus adaptations to the two fundamental hypotheses that underlie the method (Eqs. S2 and S3 of the ESM). The authors adapted the estimation of soil moisture, while maintaining a relatively straightforward implementation and a restricted number of required parameters. A computer program was developed in Python to implement the SME model in this study.

The SME method decouples soil moisture from catchment potential retention, which are lumped in the original NRCS$\mathrm{CN}$ method. Several simplifying assumptions are then applied in order to derive an expression for soil moisture on daily time steps, using a 5-day antecedent rainfall condition $P_{5}$ (Eq. S8 of the ESM). The principal assumption in formulating this soilmoisture equation is that the catchment is completely dry prior to the 5-day antecedent precipitation window $P_{5}$. This assumption is, however, generally invalid for temperate regions, regions with regular winter snowfall, and for urban landscapes where, despite potential decreases in infiltration, impervious surfaces and compacted soils may lead to prolonged soilmoisture retention due to reduced ET (Bhaskar et al. 2016). Antecedent rainfall may be taken over longer time periods $\left(P_{x}\right.$ for $x>5$ ) for calculations, but this does not resolve the issue of subjectivity in choosing an antecedent moisture window, and subsequent disregard of conditions prior to that window.

Given the significant dependence of runoff generation on antecedent moisture conditions in many catchments (e.g. Bennett et al. 2018; Hrachowitz et al. 2013; Penna et al. 2011), an attempt to further improve upon soil-moisture characterization is merited. An alternative is the antecedent precipitation index (Fedora and Beschta 1989; Kohler and Linsley 1951), which is proposed here to replace $P_{5}$. The antecedent precipitation index (API) applies an exponential decay factor over a rainfall timeseries, in order to estimate the amount of prior rainfall that may be contributing to current soil-moisture conditions. APIs are regularly used as soil-moisture proxies in rainfall-runoff modeling (e.g. Bennett et al. 2018; Descroix et al. 2002; Ma et al. 2014; Woldemeskel and Sharma 2016). Various, closely related formulations are given in the literature, and a generalized form of the API is used in this study:

$\mathrm{API}=\sum_{t=1}^{T} P_{-t} \times k^{t}$

In Eq. (1), $T$ is the total number of time steps in the series, $t=1,2, \ldots, T$ are the individual time steps, and $k$ is a dimensionless decay factor, with $0<k<1$ (often in the range of 0.6 0.99 for temperate areas). $P_{-t}$ is the amount of precipitation at a prior time step $-t$. As $t$ increases, the term $k^{t}$ vanishes. The factor $k$ is conceptualized as representing how quickly moisture is lost from a catchment through any process: higher values of $k$ represent a slow draining landscape (including soil-moisture drainage), and lower values represent a quickly draining landscape (Ali et al. 2010; Lee and Huang 2013; Woldemeskel and Sharma 2016). In reality, the decay factor is proportional to evapotranspiration and likely related to water table depth, and thus should vary seasonally (Pui et al. 2011). In practice, it is often taken as a constant through time, assumed to represent average annual conditions. The API rids the need for the user to determine an arbitrary, fixed-window sum of antecedent precipitation, at the expense of having to estimate the parameter $k$.

For this study, values of $k$ between 0.8 and 0.95 for daily time steps were considered. The calculated API was in fact relatively insensitive within this range, with an average difference of $2.5 \mathrm{~mm}$ between the API using $k=0.8$ and $k=0.95$. Without further information to constrain this value, a value of $k=0.9$ was selected for the API. The length of $T$ for the API covered the entire timeseries (2007-2018) on daily time steps.

The original SME equation for soil moisture, $M$, (Eq. S8 in the ESM) is thus modified and applied here as:

$M=\beta\left[\frac{\left(A P I-\lambda S_{0}\right) S_{0}}{A P I+(1-\lambda) S_{0}}\right]$ for API $>\lambda S_{0}$

where $\beta$ (dimensionless) represents the fraction of antecedent 
precipitation that is contributing to soil moisture, $S_{0}$ (units of depth) represents maximum potential retention of a catchment, and $\lambda$ (dimensionless) is the so-called initial abstraction ( $\left.I_{\mathrm{a}}\right)$ coefficient, where $I_{\mathrm{a}}=\lambda S_{0}$.

From the decoupling of soil moisture and maximum potential retention, $S_{0}$ is determined as a function of physical catchment characteristics including soil type, unsaturated zone depth, land cover, and vegetation types. Initial $S_{0}$ values can be approximated with values of $S$ in dry conditions from the NRCS-CN method (Mishra and Singh 2003; USDA Natural Resources Conservation Service 1986), and adjusted through calibration. The parameter $\lambda$ is generally deduced from geological maps, drainage tests, soil cores, climatic factors, or other aspects of the current conceptual model for the site under study. Values of $\lambda$ are referenced in literature between the ranges of 0.05 and 0.3 , and are closer to 0.05 in urbanized areas (e.g. Minnig et al. 2018; Mishra and Singh 2003). Values of $\beta$ may range between 0 and 1 , though more precise information on this parameter in literature is sparse. Further, the fraction $\beta$ is most certainly affected by the use of the API in place of $P_{5}$, and is expected to be closer to 1 in this formulation of $M$ due to the decay factor inherent to the API.

Further, it was deemed important to expand the representation of runoff beyond soil-controlled, saturation-excess overland flow. This was done by explicitly accounting for paved and drained surfaces with a preprocessing of rainfall partitioning. Runoff over paved and drained surfaces was decoupled from soil-controlled runoff dynamics with the simplified assumption that all precipitation falling onto these surfaces immediately becomes runoff. As $10 \%$ of the entire catchment is covered and connected to storm drainage, $10 \%$ of all precipitation was routed directly to runoff, and the remaining $90 \%$ of precipitation then used as input for both API and SME runoff calculations. This treatment is equivalent to routing $10 \%$ of precipitation directly into surface water via storm sewers and drainage systems. With these added considerations, the following equation for runoff $R_{\text {off }}$ is applied:

$$
\begin{aligned}
R_{\mathrm{off}} & =\frac{\left(0.9 P-I_{\mathrm{a}}\right)\left(0.9 P-I_{\mathrm{a}}+M\right)}{0.9 P-I_{\mathrm{a}}+S_{0}}+0.1 P, \text { for } 0.9 P \\
& >I_{\mathrm{a}}
\end{aligned}
$$

where $I_{\mathrm{a}}$ corresponds to rainfall interception, which is the fraction of precipitation that is lost from a catchment during a storm event through processes such as infiltration, canopy interception, or ponding at the surface (Lee and Huang 2013; Van Dijk et al. 2015). In Eq. (3), the factors of 0.9 and 0.1 will change from catchment-to-catchment depending on the ratio of area that is covered by impervious surfaces. Calculations were carried out on a daily basis and upscaled to weekly, monthly, and annual scale in order to explore storm-by-storm, seasonal, and annual runoff.

\section{Hydrograph separation}

Hydrograph separation (HS) involves dividing a hydrograph into its assumed subflow components, which consist principally of quickflow and baseflow. Baseflow corresponds to sustained streamflow during dry weather periods and is largely sourced from groundwater, where quickflow is largely sourced from surface runoff from storm events. Land development often leads to significant changes in baseflow and quickflow dynamics (Gremillion et al. 2000; Liu et al. 2013; Meriano et al. 2011).

The basic approach for hydrograph separation uses recursive digital filters (RDFs) to separate quickflow and baseflow (Chapman 1991; Nathan and McMahon 1990; Willems 2009). The RDF first proposed by Lyne and Hollick (1979), as outlined by Nathan and McMahon (1990) was applied with the EcoHydrology package available in R (Fuka et al. 2018) for this study. The filter is expressed as such:

$\mathrm{qf}_{t}=\alpha \times \mathrm{qf}_{t-1}+\frac{1+\alpha}{2} \times\left(Q_{t}-Q_{t-1}\right)$

where qf is quickflow (units of depth), $Q$ is measured streamflow (units of depth), and $\alpha$ is the filter parameter (dimensionless). It can be seen from Eq. 4 that larger values of $\alpha$ lead to lower estimates of baseflow and higher estimates of quickflow, and vice versa. For the purpose of this study, qf is assumed to correspond to surface runoff.

In most applications, $\alpha$ is set at or near the value of 0.925 proposed by Nathan and McMahon (1990), which is applied as standard practice (e.g. Bennett et al. 2018; Burns et al. 2012; Partington et al. 2012). However, the original work by Lyne and Hollick (1979) suggested varying the filter parameter between $0.75<\alpha<0.9$, and more recent work by Li et al. (2014) has demonstrated that $\alpha$ can and does widely vary between $0<\alpha<1$, depending on baseflow dynamics and the underlying conceptual model. Knowledge of land cover, soil types, water-table depth, and visual inspection of a streamflow hydrograph can be used as a preliminary assessment of potential value ranges of $\alpha$. It is generally assumed that the lower end of the hydrograph recession curve should coincide with baseflow. Visual inspection of the upper Kempttal hydrograph show that values of $\alpha$ lower than the commonly used 0.925 better portray the expected behavior of a flashier runoff response to storm events that is characteristic of urbanizing areas. For the current work, a range of values between 0.3 and 0.95 were explored with an uncertainty analysis (see section 'Uncertainty analysis' for details). 
As the river gauging station at this study site is located directly downstream of the wastewater treatment plant (WWTP), wastewater effluent is integrated into the streamflow signal, supplementing groundwater-sourced baseflow due to its relatively lagged response relative to quickflow. Because of this, a higher quantity of baseflow (and thus a lower value for $\alpha$ ) is deemed more appropriate to account for this effluent; an example hydrograph from this exercise is available in the supplementary information (Fig. S2 of the ESM). As with the SME method, HS calculations were calculated on a daily basis and upscaled to weekly, monthly, and annual scale in order to explore storm-by-storm, seasonal, and annual runoff.

\section{Streamflow, runoff, and quickflow coefficients}

The streamflow coefficient $C_{\mathrm{Q}}=Q / P$ is an often-used index to characterize the relative response of river discharge to storm events, and has been applied in numerous studies to this end (e.g. Barron et al. 2013; Penna et al. 2015; von Freyberg et al. 2018). Similarly, runoff coefficients using $R_{\text {off }}$ and qf from SME and HS calculations, respectively, can be used to specifically characterize the relative surface runoff response to storm events. These are expressed as $C_{\mathrm{Roff}}={ }{ }_{\text {off }} / P$ and $C_{\mathrm{qf}}=\mathrm{qf}^{\mathrm{f}} /{ }_{P}$, respectively. It is important to note that $C_{Q}$ only represents how much water is mobilized by a storm event, and does not track the source of water in the streamflow response (von Freyberg et al. 2018). It is only $R_{\text {off }}$, which is calculated from the SME method, that is physically derived from precipitation. All three of these coefficients were calculated over the entire timeseries in an attempt to gain insight on the proportional streamflow or runoff response from a given storm event, the potential presence of runoff inputs additional to rainfall (i.e. pre-event water, $\mathrm{CSO}$ ), and the catchment contributing area to runoff generation. These coefficients were explored as a function of both precipitation magnitude as well as antecedent precipitation conditions.

\section{Uncertainty analysis}

Uncertainty in the parameters for both runoff methods were explored. First, the SME method is a relatively new approach as compared to the original $\mathrm{CN}$ method, and plausible ranges of parameter values are less documented. To address the uncertainty for this method, a Monte Carlo sampling approach was used to generate an ensemble of 10,000 random parameter combinations from independent prior probability distributions for $S_{0}, \lambda$, and $\beta$ (Table 3; Fig. S1 of the ESM), resulting in 10,000 runoff estimates. The lower and upper limits of $S_{0}$ and $\lambda$ were constructed to be larger than the ranges of these parameters found in literature for the original $\mathrm{CN}$ method (Minnig et al. 2018; Mishra and Singh 2003; Sahu et al.
Table 3 Ranges of prior parameter values considered for SME and HS calculations

\begin{tabular}{llclr}
\hline Method & Parameter & Mean & Min & \multicolumn{1}{c}{ Max } \\
\hline SME & $S_{0}$ & 150 & 8.56 & 293.55 \\
& $\lambda$ & 0.10 & 0.002 & 0.29 \\
& $\beta$ & 0.5 & 0.01 & 0.99 \\
HS & $\alpha$ & 0.61 & 0.3 & 0.95 \\
\hline
\end{tabular}

2012). It should be noted that during construction of parameter ranges, $S_{0}$ values greater than $300 \mathrm{~mm}$ led to very minimal surface runoff estimates, and values greater than $450 \mathrm{~mm}$ led to a complete absence of surface runoff. Finally, each parameter was allowed to vary independently during the sampling process.

With regard to hydrograph separation, the filter parameter $\alpha$ was similarly tested. In this case, a manual sampling of 23 random values between 0.3 and 0.95 was carried out (Table 3).

\section{Groundwater recharge}

\section{Water balance}

In this text, the water balance calculates groundwater recharge (GWR) as the residual of relevant terms including precipitation $(P)$, evapotranspiration (ET), and surface runoff (Runoff). The basic form was calculated in the current study:

$\mathrm{GWR}=P-\mathrm{ET}-$ Runoff

Using Eq. (5), GWR was estimated on a daily basis over the entire catchment, and then upscaled to annual sums for the purpose of identifying long-term trends (i.e. dry years or wet years). The estimates of surface runoff and quickflow outlined in sections 'SME method' and 'Hydrograph separation' were used in turn as the runoff input. As reference ET inputs were available from public data, their uncertainties were not explored, and the same ET dataset was used for water balance calculations.

Human systems in general, and urban systems in particular, may contain additional artificial inputs into a groundwater recharge balance such as sewer leakage, water mains leakage, or irrigation return flow (Bhaskar et al. 2016). However, such sources are highly uncertain and are difficult to identify, particularly when their impact is small or is balanced out with artificial losses such as groundwater pumping. The net impact of these artificial sources on the overall mass balance is expected to be minimal at our study site and without further data, are therefore not considered. 


\section{HBV Light model}

HBV Light is a rainfall-runoff model developed by Seibert and Vis (2012) as an adaptation to the original HBV model developed by Bergström (1976). HBV Light is regularly applied by hydrologists to partition measured streamflow into its assumed subcomponents, and has been used in numerous studies for various objectives (e.g. Etter et al. 2017; Gebrehiwot et al. 2013; Griessinger et al. 2016; Orth et al. 2015). Thorough overviews are available in literature (Bergström and Lindström 2015; Seibert 1999; Seibert and Vis 2012). The model is built around the following water balance equation:

$$
P-\mathrm{AET}-Q=\frac{d}{d t}(\mathrm{SP}+\mathrm{SM}+\mathrm{SUZ}+\mathrm{SLZ}+\text { lakes })
$$

where $P$ is precipitation, AET is evapotranspiration, $Q$ is river discharge, SP is snow pack, SM is soil moisture, and SUZ and SLZ are storage in upper and lower subsurface zones, respectively. The model output variable labeled as recharge is conceptualized as all water infiltrating from the surface into both upper and (SUZ) and lower (SLZ) subsurface zones. All variables are in units of depth over a specified time step. In its simplest form, timeseries for precipitation, air temperature, river discharge, and potential ET (PET) are needed, where river discharge is fitted to calibrate model parameters. AET is then calculated from PET and air temperature within the model. The model may be solved in either a lumped-catchment manner or in a semidistributed manner by defining elevation and vegetation zones. Model structures are available that account for multiple groundwater bodies, snow packs, or a heterogeneous unsaturated zone.

For this study, the standard HBV Light model structure was applied in order to represent both unsaturated and saturated zones. Five different elevation zones and one vegetation zone were defined in order to create a semidistributed framework. There are in fact three streamflow components in the model structure that correspond to the groundwater recharge output from SUZ and SLZ. These components are labeled $Q_{0}$, $Q_{1}$, and $Q_{2}$, and account for unsaturated zone and shallow percolation contribution into streamflow $\left(Q_{0}, Q_{1}\right)$, followed by baseflow that is connected to deep percolation $\left(Q_{2}\right)$. $Q_{0}$ is calculated as 0 except during strong storm events and when soil moisture is above a predefined threshold, and $Q_{1}$ is activated during most storm events as well as when soil moisture is above a second predefined threshold. Therefore, for the purpose of this study, $Q_{0}$ and $Q_{1}$ were subtracted from the given recharge variable in order to calculate GWR that is consistent with the empirical water balance applied for this study.
Built-in calibration methods are available to explore model uncertainty. Automatic sampling of parameter values between user-defined bounds can be carried out with either Monte Carlo (MC) random sampling or a Genetic Algorithm and Powell optimization (GAP). Parameter sets are then evaluated by applying one or more objective functions between simulated and observed streamflow, and best-fit combinations are determined by optimizing the chosen objective function(s). The model was calibrated between the years 2008-2012 and validated from 2013 to 2016, using both MC and GAP to find the best parameter sets. From these, the six best performing parameter sets were selected each from the MC and GAP simulations, for a total of six optimized estimates. Three objective functions were used to assess model performance: efficiency $R_{\text {eff }}, \log$ of efficiency $\log R_{\text {eff, }}$ and the coefficient of determination $R^{2}$. Optimal values for each of these objective functions is 1 . Results only from the validation period 20132016 are presented in this study.

\section{Results}

\section{Runoff response to rainfall}

\section{Streamflow dynamics}

The streamflow coefficient $C_{\mathrm{Q}}$ is plotted in Fig. 2 against precipitation (Fig. 2a), and then as the API, over daily timesteps (Fig. 2b). The relationship is shown for days where $P>10 \mathrm{~mm}$; amounts below $10 \mathrm{~mm}$ in 1 day were generally observed to generate little to no streamflow response, which has been observed in studies of similar climate (e.g. Thomas and Tellam 2006). Figure 2a shows that the streamflow coefficient for precipitation amounts $>30 \mathrm{~mm} /$ day does not exceed 0.5 . In contrast, when $C_{\mathrm{Q}}$ is compared to the API (Fig. 2b), a positive and exponential relationship is exposed. These relations suggest that higher antecedent catchment moisture is a strong indicator for greater streamflow response, whereas higher absolute rainfall does not seem to lead to a relatively higher streamflow response. Conditions when $C_{\mathrm{Q}}>1$ are observed for several instances when the API surpasses $30 \mathrm{~mm}$, and may be an indication of greater pre-event soil-water input or CSO, although this should be interpreted with care because $C_{\mathrm{Q}}>1$ can be influenced by the frequency of measurements, as streamflow recession can occur over periods longer than 1 day.

Figure 3 exposes the temporal relationship between streamflow, precipitation, and the API for the example year 2010 (time series for all years available in Fig. S4 of the ESM). It can be seen that the two largest storms and river discharge peaks occur immediately following a mostly dry period with a low API. It is interesting to note that during prolonged periods of increased soil moisture and consistent 
a.)

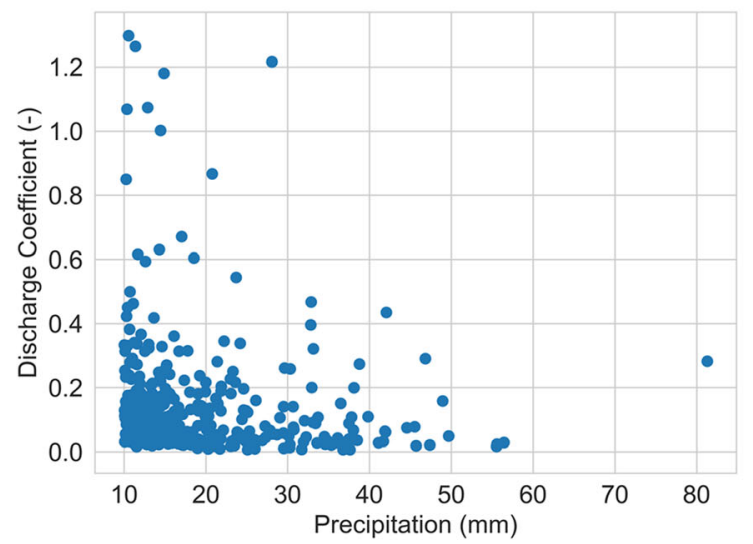

b.)

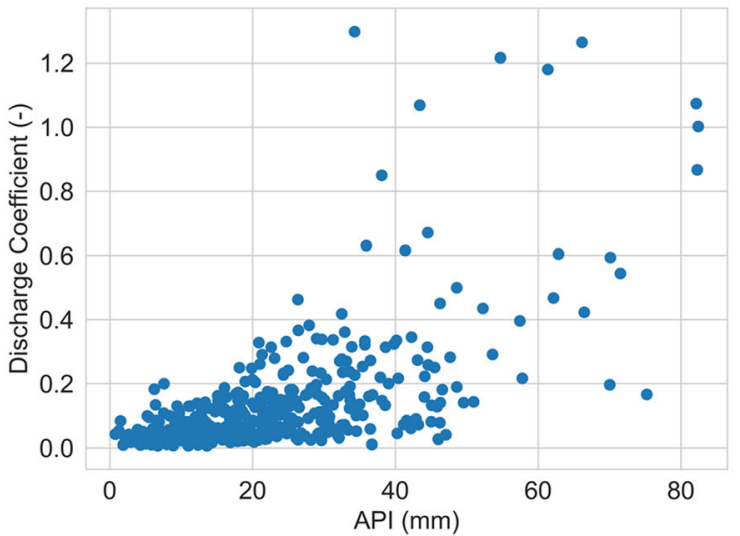

Fig. 2 Streamflow coefficient $C_{\mathrm{Q}}$ with measured discharge $Q$ as a function of a daily precipitation and $\mathbf{b}$ the antecedent precipitation index (API)

small storms, major peaks in streamflow are not always observed. A notable example in Fig. 3 is the month of July, where the API is elevated from small storms, but streamflow exhibits few major peaks. Despite increases in sealed surfaces and presence of drainage systems, it is suggested that much of the precipitation during small storms ends up infiltrating soils and recharging the aquifer rather than being lost to surface runoff.

\section{Comparing estimates of surface runoff}

The surface runoff coefficient $C_{\text {Roff }}$ was calculated using the mean values of all SME surface runoff simulations as a function of precipitation. When $C_{\text {Roff }}$ is plotted against precipitation and against the API (Fig. 4), a similar pattern to those of Fig. 2 emerges: smaller amounts of precipitation correspond more strongly to proportionally higher runoff responses, whereas higher API values correspond to proportionally higher runoff responses. Regardless that SME calculations explicitly account for direct runoff from paved surfaces, increases in precipitation do not seem to have a significant, positive impact on $C_{\text {Roff. }}$

Likewise, the quickflow coefficient $C_{\mathrm{qf}}$ was calculated using the mean values of all qf estimations, and is plotted against precipitation and then the API in Fig. 5. A major difference between $C_{\mathrm{Roff}}$ and $C_{\mathrm{qf}}$ is in their maximum values. Whereas the maximum value of $C_{\text {Roff }}$ is below 0.5 , the maximum value of $C_{\mathrm{qf}}$ surpasses 1 . While SME runoff estimates are 'blind' to additional contributions to storm runoff, any additional inputs to quickflow (i.e. pre-event water, CSO) are integrated into the hydrograph such that $C_{\mathrm{qf}}$ is not subject to the constraint of precipitation as an upper threshold. Further, contrary to the discharge coefficient $C_{\mathrm{Q}}$, lags in streamflow recession are assumed to have less of an impact as much of the recession limb is filtered out when calculating qf.

Simulations of the resulting surface runoff time series for the example year 2010 are plotted on a weekly and monthly basis in Fig. 6, where the solid and dashed lines represent the average of all simulations, and the shaded areas represent their

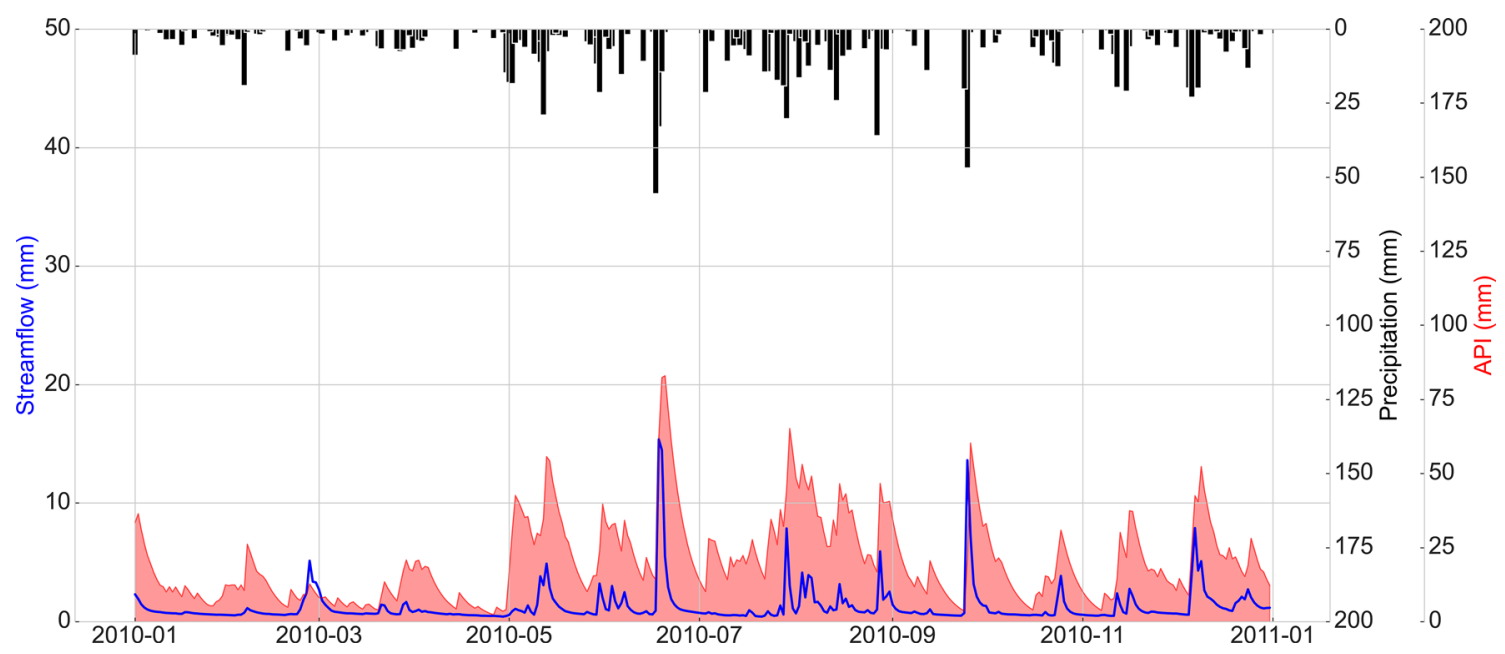

Fig. 3 Daily time series of precipitation, river discharge, and calculated API. Time series for all years included in this study are available in Fig. S4 of the ESM 

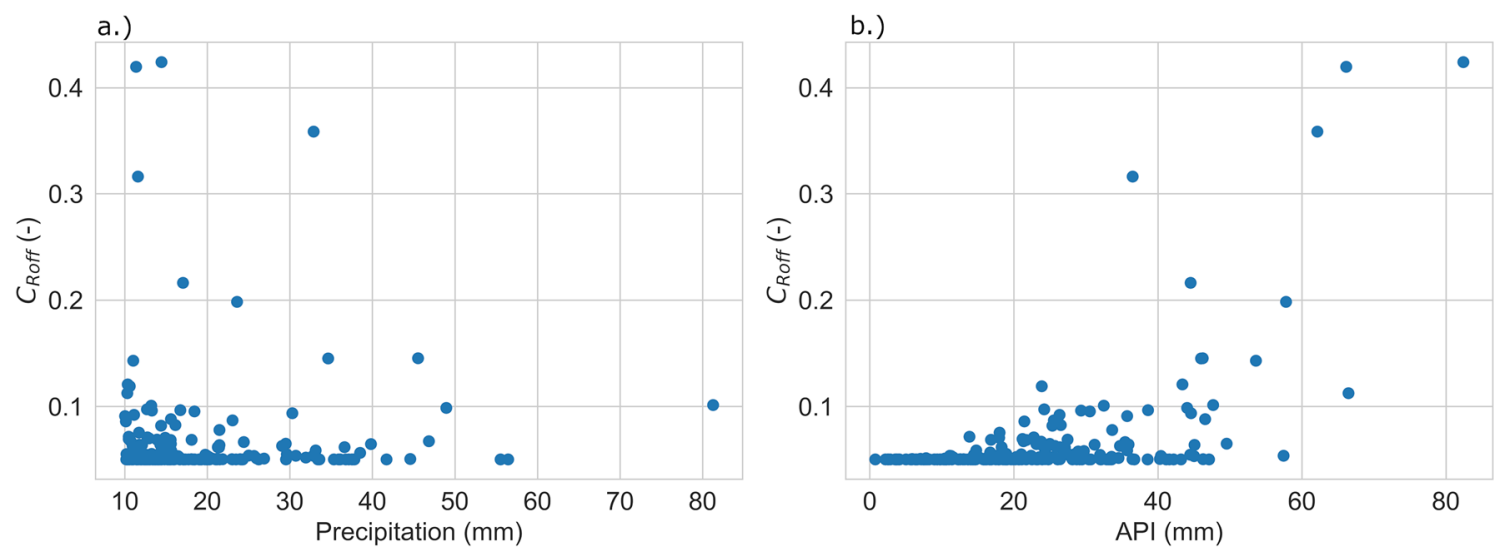

Fig. 4 SME runoff coefficient $\left(C_{\text {Roff }}\right)$ as a function of a daily precipitation and $\mathbf{b}$ the API. The mean SME runoff was used to calculate $C_{\text {Roff }}$

respective standard deviations (time series for all years are available in Fig. S3 of the ESM). The weekly time scale is used to compare results on an approximately storm-by-storm basis, whereas monthly time scales are used to compare seasonal dynamics. On a weekly basis, Fig. 6 reveals that the temporal trends in runoff estimates tend to agree well for greater runoff magnitude. Greater mismatches with regard to magnitude as well as response trends are present in consistent, low levels of precipitation, where soil moisture is high - for example, storms in early August 2010. This same tendency is observed for all years (see Figs. S3.a and S3.b in the ESM). Runoff estimates on a monthly basis show good agreement in general. During the month of August, discrepancies can at least partially be attributed once again to the higher values of the API that are used for SME runoff estimates.

A summary of the runoff simulations for both SME runoff and HS quickflow are visualized in Fig. 7 (numeric values may be referenced in Table S1 in the ESM). The average runoff estimates from the SME method are generally lower than quickflow estimates from HS during moderate and wet years, yet higher during dry years. These relatively higher SME runoff estimates during dry years can partially be attributed to the uncertainties surrounding consistent low levels of precipitation that are predominant in drier years, as opposed to large storm events. Relatively higher SME estimates may also be due to the direct routing of precipitation over impervious areas into runoff, such that even moderate storms will lead to a small runoff response estimated using the SME method. For its part, overall higher values of surface runoff estimated from HS may be due to additional inputs to streamflow (such as sewer effluent) that are not fully filtered out with $\alpha$.

\section{Annual groundwater recharge}

\section{Groundwater balance of the upper Kempttal catchment}

As groundwater recharge generally portrays a slower response time than surface runoff, annual estimations were explored. Figure 8 compares annual groundwater recharge calculated with the two runoff estimates, where the $P$ and ET inputs were kept constant. The magnitude of the two resulting GWR estimates are generally in good agreement, and the inter-annual recharge trend is coherent between the two water balances as a.)

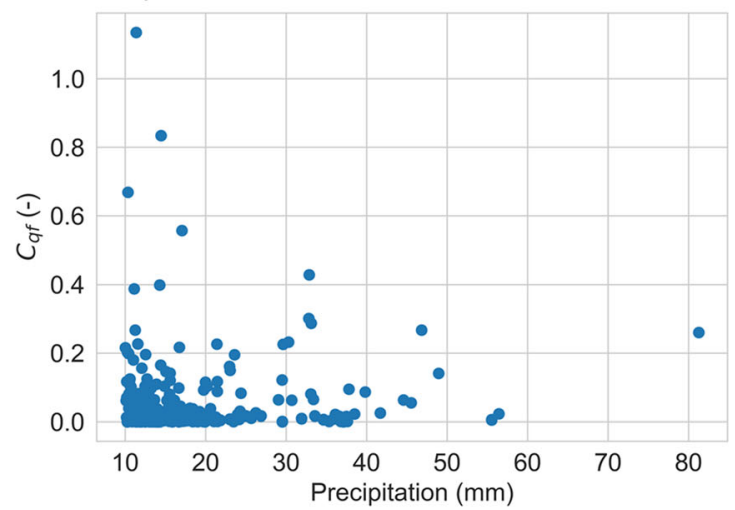

b.)

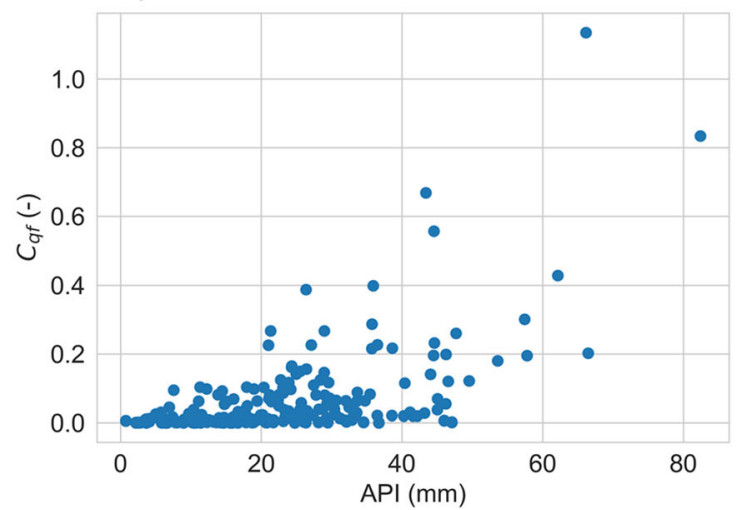

Fig. 5 HS quickflow runoff coefficient $\left(C_{\mathrm{qf}}\right)$ as a function of a daily precipitation and $\mathbf{b}$ the API. The mean quickflow estimates were used to calculate $C_{\text {qf }}$ 

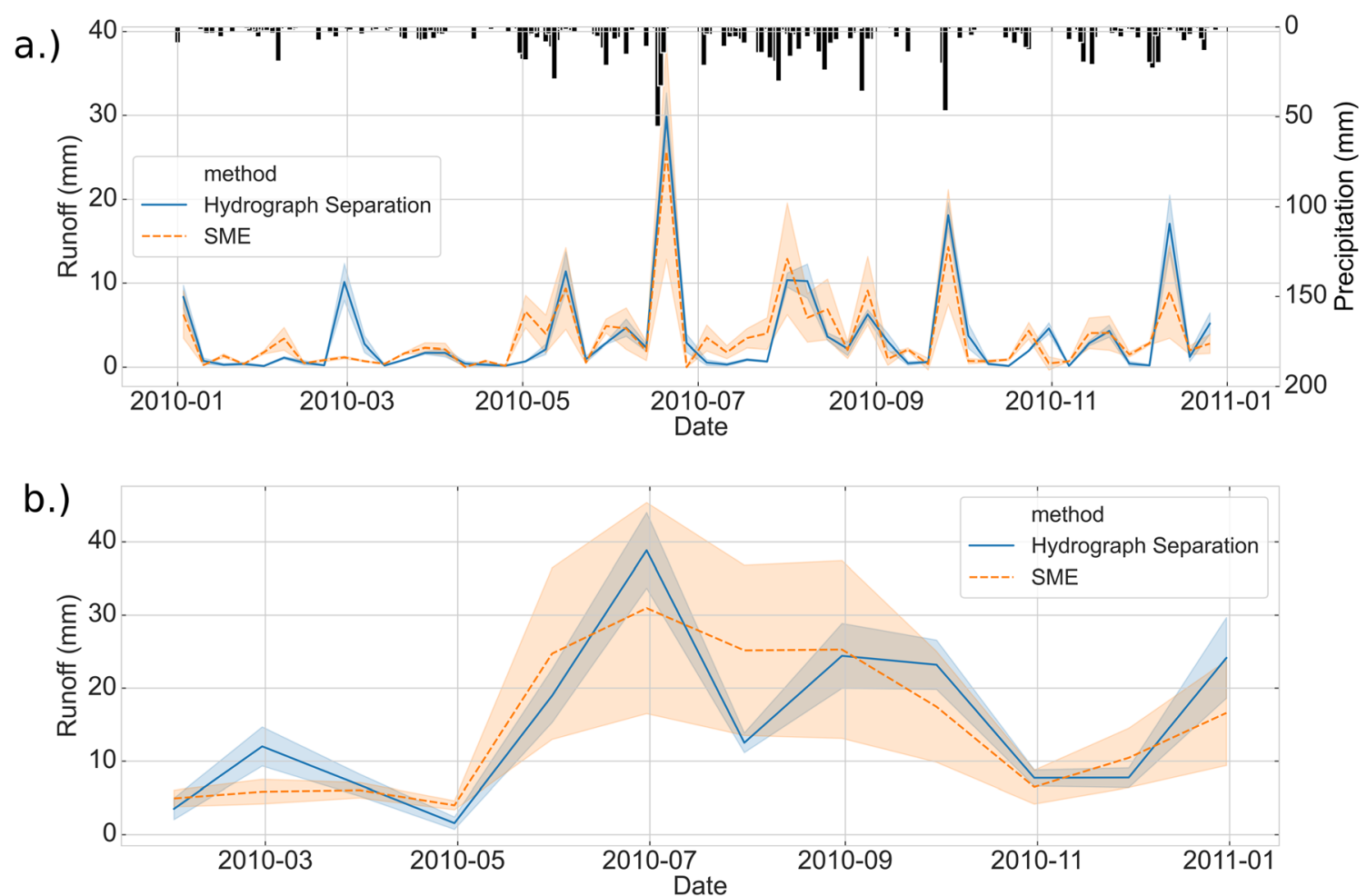

Fig. 6 Time series comparison of surface runoff estimated from the SME method versus HS on a weekly and $\mathbf{b}$ monthly time steps. Additional time series over the entire course of study can be found in Fig. S3 of the ESM

well. The largest difference between these estimates is on the order of $50 \mathrm{~mm} / \mathrm{year}$; a small and satisfactory difference. However, despite accounting for runoff uncertainty, there is a pattern of the HS quickflow input leading to lower recharge estimates between the years 2012 to 2018 , consistent with higher runoff values in those years. This is likely a carryover effect to the fact that SME runoff estimates only account for losses from precipitation, where HS quickflow integrates potential signals from pre-event soil-moisture losses.

Results from the water balance were then compared to estimates of groundwater recharge from the HBV Light model for the years 2013-2016, which is the period where all three methods are covered. Figure 9 shows the spread of these estimates, where the boxplots represent all simulations for each method (numerical values may be referenced in Table S2 in the ESM). In general, the average estimates between the water balance and the HBV Light model are also in good agreement. For the years 2013 and 2014, when annual precipitation was close to its 10-year average, the average difference between the lowest and highest recharge estimates is below $100 \mathrm{~mm} /$ year. However, differences increase for both the extremely dry year of 2015 and the wet year of 2016, reaching approximately $200 \mathrm{~mm} /$ year of difference in 2016. Indeed, such reduced performance under extreme conditions is a known issue for lumped models (Crosbie et al. 2011; Moeck et al. 2018). Regardless of these differences, estimates of groundwater recharge generally equate to $40-45 \%$ of annual precipitation recharging the aquifer from all methods. The exception to this is seen during the particularly dry years of 2015 and of 2018, where recharge estimates dropped as low as $20 \%$ of annual precipitation.
Fig. 7 Sum of annual surface runoff estimated including all simulations for both methods for each year of the study period

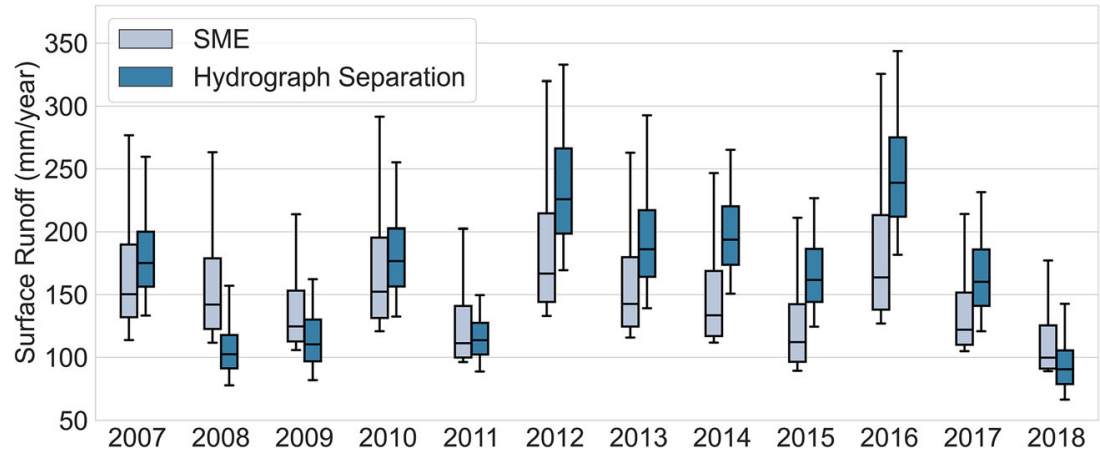


Fig. 8 Annual time series comparing recharge estimates via water balance. Solid lines represent the mean value from all simulations, and shaded areas represent the standard deviation

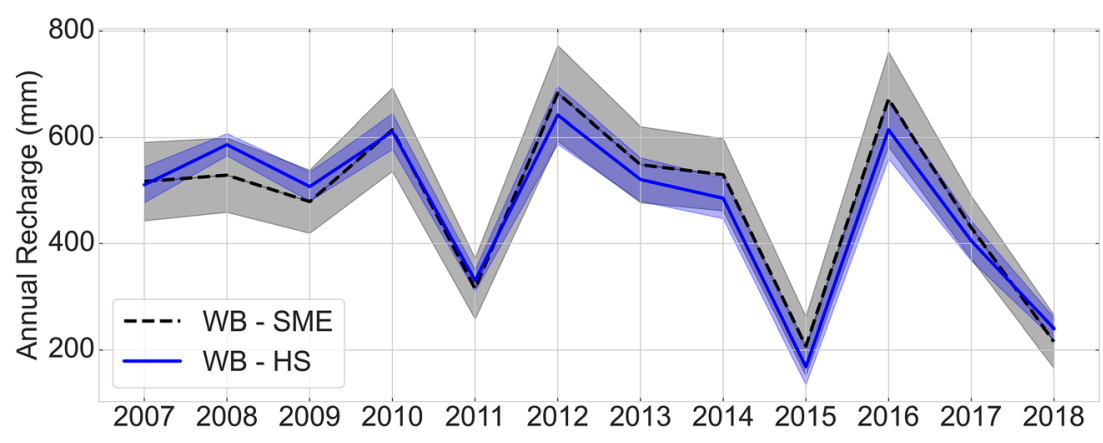

Performance metrics of the HBV Light model runs are available in Table S3 of the ESM. It can be seen in Fig. 9 that, despite a formal calibration in the HBV Light model against streamflow, the inter-quartile range of HBV Light groundwater recharge estimates is larger than is found with the water balance. This spread is certainly affected by uncertainties in ET in addition to runoff uncertainties. While the same reference ET data was used for the water balance calculations, the HBV Light model calculates AET internally from PET, using temperature and soil moisture as a limiting factor.

\section{Groundwater recharge across Switzerland}

To further assess the relative performance of GWR calculations, results were compared with additional estimates of GWR found at a number of study sites across Switzerland. The studies listed in Table 4 were all carried out in unconfined catchments similar to the Kempttal (based on geographical proximity, elevation, climatic forcing functions, geology, and land cover). These GWR estimates are plotted together as a function of annual precipitation in Fig. 10.

Different objectives, approaches and assumptions were used in each of the studies listed in Table 4. Baillieux et al. (2015) investigated the use of transfer functions

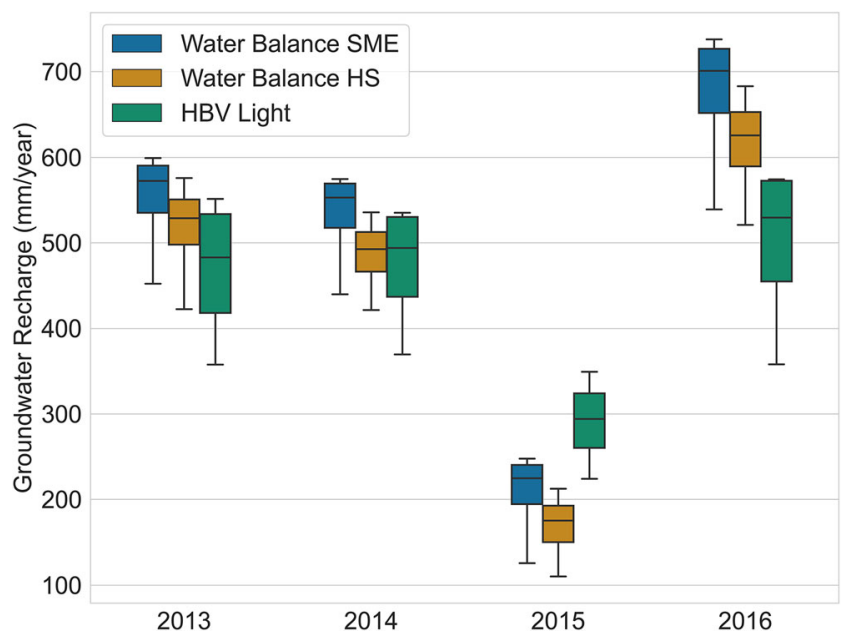

Fig. 9 Comparison of annual recharge estimates with HBV Light model results for overlapping years 2013-2016 and the importance of recharge estimates on contaminant transport dynamics. Epting et al. (2021) investigated the impact of climate change, and of groundwater temperature increase in particular, on recharge rates for aquifers in high-production valleys all across the Swiss plateau. Minnig et al. (2018) carried out a groundwater balance over four time periods of increasing urbanization, explicitly accounting for reduced ET under paved surfaces plus input from sewer leakage and water mains losses. Mdaghri-Alaoui and Eugster (2001) estimated groundwater recharge for an aquifer with historical nitrate contamination, with particular focus on quantifying evapotranspiration. Moeck et al. (2016) explored the effects of different hydrological model structures, calibration on groundwater recharge estimates within the context of climate change, using a lysimeter to construct a reference model. Moeck et al. (2020b) evaluated the impact of uncertainties in hydraulic conductivities and boundary conditions on flow pathways for a managed aquifer recharge system. Finally, Stoll et al. (2011) made use of groundwater and climate models to assess the impact of climate change on water fluxes, and the uncertainties tied to downscaling large-scale to local-scale models.

Regardless of these different approaches, estimates of annual groundwater recharge as well as the ratio of recharge to precipitation are in satisfactory agreement between all of these studies. This serves as an indirect validation of the methods applied in this study, and shows that the magnitude of groundwater recharge found here for the Kempttal catchment is in a similar range as what is found by other independent studies.

\section{Discussion}

The results presented in this study have indicated that reasonable estimates of surface runoff and groundwater recharge for an urbanizing catchment can be obtained with minimal data using empirical methods. Comparing annual groundwater recharge estimates with Swiss case studies found in literature further served as a useful tool to confirm that the results found here are within a credible range. In spite of satisfactory 
Table 4 Compilation of groundwater recharge studies across Switzerland in comparison to this study (data in italic). Note: values for this study are averaged over the entire 12-year period and appear in italic font

\begin{tabular}{|c|c|c|c|c|c|c|c|}
\hline Study & $P[\mathrm{~mm} /$ year $]$ & GWR $[\mathrm{mm} /$ year $]$ & $\begin{array}{l}\text { GWR } \\
{[\%}\end{array}$ & Notes & $\begin{array}{l}\text { Distance to Kempttal } \\
\text { Catchment }(\mathrm{km})\end{array}$ & $\begin{array}{l}\text { Study } \\
\text { Scale }\end{array}$ & Land use \\
\hline This study & 1,095 & 448 & $41 \%$ & Kempttal Catchment & 0 & $25 \mathrm{~km}^{2}$ & Mixed \\
\hline Stoll et al. (2011) & 1,135 & 588 & $52 \%$ & Baltenswil, Aathal aquifer & 12 & $9 \mathrm{~km}^{2}$ & Agriculture \\
\hline Minnig et al. (2018) & 947 & 374 & $40 \%$ & Dübendorf Municipality & 12 & $13.6 \mathrm{~km}^{2}$ & Urban \\
\hline Epting et al. (2021) & 1,178 & 681 & $58 \%$ & Eulach Catchment & 15 & $9.3 \mathrm{~km}^{2}$ & Urban \\
\hline Moeck et al. (2016) & 900 & 543 & $60 \%$ & $\begin{array}{l}\text { Zürich Reckenholz } \\
\text { lysimeter }\end{array}$ & 20 & Plot scale & Agriculture \\
\hline Baillieux et al. (2015) & 980 & 510 & $52 \%$ & Wohlenschwil & 50 & $3 \mathrm{~km}^{2}$ & Agriculture \\
\hline Epting et al. (2021) & 1,111 & 554 & $50 \%$ & Ergolz Catchment & 83 & - & Mixed \\
\hline Moeck et al. (2020b) & 730 & 423 & $58 \%$ & Hardwald, Basel-Landschaft & 97 & $10 \mathrm{~km}^{2}$ & Mixed \\
\hline Epting et al. (2021) & 1,296 & 793 & $61 \%$ & Birs Catchment & 100 & $50 \mathrm{~km}^{2}$ & Urban \\
\hline $\begin{array}{l}\text { Mdaghri-Alaoui and } \\
\text { Eugster (2001) }\end{array}$ & 865 & 297 & $35 \%$ & Areuse River delta & 180 & - & Mixed \\
\hline
\end{tabular}

performance, uncertainties persist in the estimation of surface runoff on shorter timescales. This highlights the difficulty in capturing specific processes that influence the runoff response (and resulting groundwater recharge) without more robust databases. However, the necessity to characterize such responses in ungauged, data-poor catchments has been widely recognized (Hrachowitz et al. 2013). Better constraining physical catchment properties such as topography, vegetation type, or land use, may be of equal, or even greater, value for improving understanding of flow processes in the absence of robust, high temporal resolution databases (e.g. Carlier et al. 2018; Moeck et al. 2020a; Tweed et al. 2007). Indeed, an important step in all CN-based methods is the determination of soil types (USDA Natural Resources Conservation Service 1986). In the case of the SME method, constraining maximum catchment potential retention and soil moisture using physical catchment characteristics could improve estimates of surface

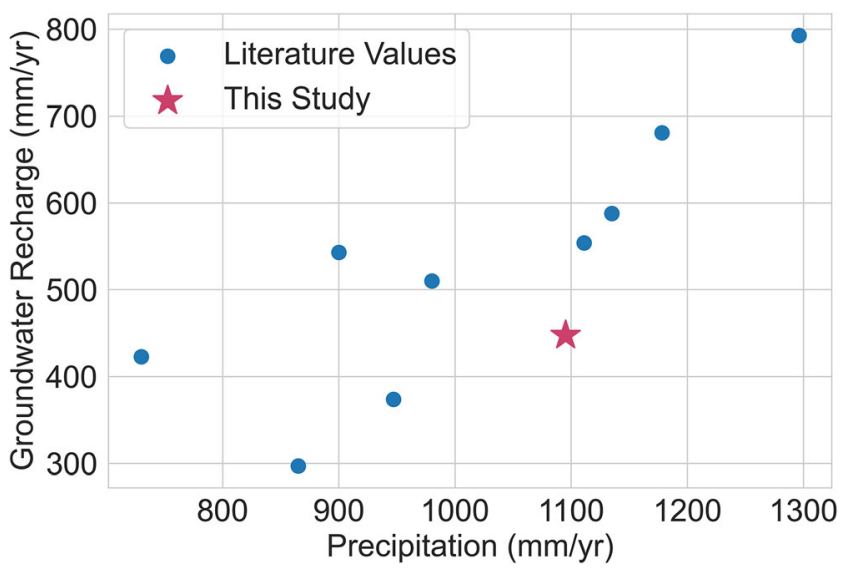

Fig. 10 Annual average groundwater recharge as a function of precipitation for study sites across Switzerland runoff without increasing the demand for on-the-ground measurement data.

\section{Assessment of conventions in estimation methods}

An important step in this study was to critically assess appropriate values of the parameters used in both runoff estimation methods. For the well-known hydrograph separation using a recursive digital filter, the commonly used value for the filter parameter $\alpha=0.925$ was interrogated by exploring a wider range of parameter values, as suggested in several recent studies (e.g. Li et al. 2014). It has long been recognized that at least in some catchments, pre-event baseflow plays a significant role in the storm runoff response (Klaus and McDonnell 2013), which would be better represented by lower values of $\alpha$. It is believed that variations in the filter parameter should regularly be included in uncertainty analysis when applying the RDF to a hydrograph.

With respect to the SME method, by implementing the exponential decay factor through the API in place of $P_{5}$, the method is one step closer to representing a more continuous accounting of soil moisture, removing the assumptions tied to catchment dryness prior to a user-defined window as identified by the authors of the method. Use of the API could be further strengthened by adjusting $k$ as a function of time in order to account for seasonal differences in catchment moisture retention. Some authors have additionally determined the value of this decay factor as a function of physical processes within a given catchment (Descroix et al. 2002).

The second modification to the SME method, of rerouting a fixed percentage of rainfall directly into runoff, was an attempt to capture some of the runoff dynamics that are inherent in urban areas with impervious surfaces, albeit in a simplified manner. In future work, it would be of great value to include a 
measure of the level of connectivity of impervious surfaces if using this approach. The assumption that impervious surfaces are $100 \%$ impermeable could also be explored; as noted by previous authors, roads sometimes portray 'leaky' behavior, such that some level of infiltration occurs in these areas as well (Fidal and Kjeldsen 2020).

With regard to groundwater recharge methods, the definition of recharge in the HBV Light model was critically assessed. When applying this model as a tool to estimate recharge specifically to the aquifer, the underlying conceptual model was adjusted in a way that input from the unsaturated zone was subtracted from the recharge term. In the first iteration of the model, using the recharge estimate without considering the soil-moisture variables $Q_{0}$ and $Q_{1}$, estimates of more than $70 \%$ of rainfall becoming recharge were consistently found, which is considerably higher than what is found with the water balance and with other values found in the literature noted in Table 4. With the adjustment made in the current study, HBV Light results are in close agreement with empirical water balance estimates, with the exception of extreme years.

\section{Differences in estimations as a function of data input}

When comparing simplified pluviometric versus hydrographic methods to estimate runoff, many differences are drawn directly from the data input. Indeed, differences in even the most accurate of estimates are to be expected, as each data type only contains part of the story. For this reason, determining one method as being 'better' is evasive. The pluviometric calculations made here inherently assume an immediate response to rainfall, and that the amount of precipitation serves as the upper limit of potential surface runoff. For its part, streamflow is an integrated signal of any present runoff inputs and their relative time lags. While most of the information that is being sought is present in the signal, the difficulty lies in accurately identifying and separating these different signals (Klaus and McDonnell 2013). In addition, using a hydrograph to estimate direct storm runoff has an inherent assumption that all storm runoff is directly routed into a stream, which is not always the case (Brandes et al. 2005). In the Kempttal catchment, the dynamics of sewer effluent and combined sewer overflow, for example, are a notable source of uncertainty when using hydrograph separation. Such inputs, if not properly quantified, could lead to over-estimations of surface runoff from precipitation. However, the strength of comparing different approaches comes from the same source as their difficulties; there is a potential to use such discrepancies in estimates to identify system unknowns. When possible, it is always suggested to apply multiple methods when estimating the water balance using empirical methods and minimal data.

\section{Importance of the runoff-recharge relationship}

There are many important sources, processes, and interactions that impact groundwater recharge. The current study was motivated by the fact that runoff carries particular importance with regard to water quality. This increased risk of quality degradation is notably relevant in human-impacted areas due to the cocktail of chemicals that are present in such environments (e.g. Barlow et al. 2012; Hollender et al. 2018). Pollutants carried with runoff from the surface can make their way into the groundwater in several ways - through the use of infiltration basins, through combined sewer overflow during storms, and through groundwater interactions with qualityimpacted surface water, to name a few.

As a final consideration, when studying changes in the water cycle in a changing environment, it is important to keep in mind that relative changes of each input are occurring on top of the absolute changes of each. While the latter was the focus of the current study, it is nonetheless worth mentioning that increases in runoff do not necessarily signal a decrease in overall groundwater recharge. Particularly in urban areas, the observed increases in surface runoff that result from impervious surfaces can be accompanied by decreases in actual evapotranspiration due to these same impervious surfaces, which can in fact lead to an increase in recharge rather than a decrease in these areas (Barron et al. 2013; Brandes et al. 2005; Minnig et al. 2018). While these relative changes were beyond the scope of this study, the interested reader may refer to literature (Appleyard 1995; Bhaskar et al. 2015; Feng et al. 2012; Sharp 2010; Wittenberg and Sivapalan 1999) for a more in-depth discussion on the feedback between ET, runoff, and recharge.

\section{Summary and conclusions}

This study has compared multiple methods to estimate surface runoff and its impact on groundwater recharge in the small urbanizing Kempttal catchment on the Swiss Plateau. Straightforward methods with low data requirements were chosen in order to test their appropriateness in changing environments. Two approaches to estimate surface runoff- one pluviometric and one hydrographic - were applied, with modifications that attempt to better capture soil-moisture accounting and to explicitly account for runoff from impervious surfaces. The results were used in a water balance to calculate groundwater recharge for the shallow, unconfined aquifer within the study catchment. To evaluate the accuracy of these water balance estimates, a comparison was made to additional estimates of groundwater recharge using the conceptual HBV Light model. Finally, these recharge estimates were assessed against several literature studies from similar catchments in Switzerland. From these results, an approximate range of 
groundwater recharge was obtained on a spatial scale, offering insight into the sources of uncertainty in both runoff and groundwater recharge estimates.

Supplementary Information The online version contains supplementary material available at https://doi.org/10.1007/s10040-021-02385-1.

Acknowledgements The authors would like to express their gratitude to the Swiss federal authorities, Zürich cantonal authorities, and Fehraltorf municipal authorities for the datasets they have made available. We would also like to thank all members of the Swiss Federal Institute of Aquatic Science \& Technology's (Eawag) Hydrogeology Group, past and present, for their support and discussions.

Funding Open Access funding provided by Lib4RI - Library for the Research Institutes within the ETH Domain: Eawag, Empa, PSI \& WSL. Funding for this research was provided by the EU Horizon 2020 Marie Curie Innovative Training Network INSPIRATION (grant agreement No 675120).

\section{Declarations}

Conflict of interest The authors declare no conflict of interest.

Open Access This article is licensed under a Creative Commons Attribution 4.0 International License, which permits use, sharing, adaptation, distribution and reproduction in any medium or format, as long as you give appropriate credit to the original author(s) and the source, provide a link to the Creative Commons licence, and indicate if changes were made. The images or other third party material in this article are included in the article's Creative Commons licence, unless indicated otherwise in a credit line to the material. If material is not included in the article's Creative Commons licence and your intended use is not permitted by statutory regulation or exceeds the permitted use, you will need to obtain permission directly from the copyright holder. To view a copy of this licence, visit http://creativecommons.org/licenses/by/4.0/.

\section{References}

Ajmal M, Waseem M, Ahn J-H, Kim T-W (2016) Runoff estimation using the NRCS slope-adjusted curve number in mountainous watersheds. J Irrig Drain Eng 142:04016002. https://doi.org/10.1061/ (asce)ir.1943-4774.0000998

Ali S, Ghosh NC, Singh R (2010) Rainfall-runoff simulation using a normalized antecedent precipitation index. Hydrol Sci J 55:266274. https://doi.org/10.1080/02626660903546175

Appleyard S (1995) The impact of urban development on recharge and groundwater quality in a coastal aquifer near Perth. Western Australia Hydrogeol J 3:65-75. https://doi.org/10.1007/ s100400050072

Arnold JG, Allen PM (1999) Automated methods for estimating baseflow and ground water recharge from streamflow records. J Am Water Resour Assoc 35:411-424. https://doi.org/10.1111/j.1752-1688. 1999.tb03599.x

Arnold JG, Moriasi DN, Gassman PW, Abbaspour KC, White MJ, Srinivasan R, Santhi C, Harmel RD, Van Griensven A, Van Liew MW, Kannan N, Jha MK (2012) SWAT: model use, calibration, and validation. Trans ASABE 55:1491-1508

Baillieux A, Moeck C, Perrochet P, Hunkeler D (2015) Assessing groundwater quality trends in pumping wells using spatially varying transfer functions. Hydrogeol J 23:1449-1463. https://doi.org/10. 1007/s10040-015-1279-5

Bakker M, Schaars F (2019) Solving groundwater flow problems with time series analysis: you may not even need another model. Groundwater 57:826-833. https://doi.org/10.1111/gwat.12927

Bakker M, Post V, Langevin CD, Hughes JD, White JT, Starn JJ, Fienen MN (2016) Scripting MODFLOW model development using Python and FloPy. Groundwater 54:733-739. https://doi.org/10. 1111/gwat.12413

Barlow JRB, Kingsbury JA, Coupe RH (2012) Changes in shallow groundwater quality beneath recently urbanized areas in the Memphis, Tennessee area. J Am Water Resour Assoc 48:336-354. https://doi.org/10.1111/j.1752-1688.2011.00616.x

Barron OV, Barr AD, Donn MJ (2013) Effect of urbanisation on the water balance of a catchment with shallow groundwater. J Hydrol 485:162-176. https://doi.org/10.1016/j.jhydrol.2012.04.027

Bartlett MS, Parolari AJ, McDonnell JJ, Porporato A (2016) Beyond the SCS-CN method: a theoretical framework for spatially lumped rainfall-runoff response. Water Resour Res 52:4608-4627. https:// doi.org/10.1002/2015WR018439

Bennett B, Leonard M, Deng Y, Westra S (2018) An empirical investigation into the effect of antecedent precipitation on flood volume. $\mathrm{J}$ Hydrol 567:435-445. https://doi.org/10.1016/j.jhydrol.2018.10.025

Bergström S (1976) Development and application of a conceptual runoff model for Scandinavian catchments. Report RH07, SMHI Norrköping, Norrköping, Sweden

Bergström S, Lindström G (2015) Interpretation of runoff processes in hydrological modelling-experience from the HBV approach. Hydrol Process 29:3535-3545. https://doi.org/10.1002/hyp.10510

Bhaskar AS, Welty C, Maxwell RM, Miller AJ (2015) Untangling the effects of urban development on subsurface storage in Baltimore. Water Resour Res 51(2):1158-1181. https://doi.org/10.1002/ 2014WR016039

Bhaskar AS, Beesley L, Burns MJ, Fletcher TD, Hamel P, Oldham CE, Roy AH (2016) Will it rise or will it fall? Managing the complex effects of urbanization on base flow. Freshw Sci 35:293-310. https://doi.org/10.1086/685084

Brandes D, Cavallo GJ, Nilson ML (2005) Base flow trends in urbanizing watersheds of the Delaware River basin. J Am Water Resour Assoc 41:1377-1391. https://doi.org/10.1111/j.1752-1688.2005.tb03806. $\mathrm{x}$

Brunner P, Bauer P, Eugster M, Kinzelbach W (2004) Using remote sensing to regionalize local precipitation recharge rates obtained from the chloride method. J Hydrol 294:241-250. https://doi.org/ 10.1016/j.jhydrol.2004.02.023

Burns MJ, Fletcher TD, Walsh CJ, Ladson AR, Hatt BE (2012) Hydrologic shortcomings of conventional urban stormwater management and opportunities for reform. Landsc Urban Plan 105:230 240. https://doi.org/10.1016/j.landurbplan.2011.12.012

Burri NM, Weatherl RK, Moeck C, Schirmer M (2019) A review of threats to groundwater quality in the Anthropocene. Sci Total Environ 684:136-154. https://doi.org/10.1016/j.scitotenv.2019.05. 236

Carlier C, Wirth SB, Cochand F, Hunkeler D, Brunner P (2018) Geology controls streamflow dynamics. J Hydrol 566:756-769. https://doi. org/10.1016/j.jhydrol.2018.08.069

Chapman TG (1991) Comment on "Evaluation of automated techniques for base flow and recession analyses" by R J Nathan and T A McMahon. Water Resour Res 27:1783-1784. https://doi.org/10. 1029/91WR01007

Crosbie RS, Binning P, Kalma JD (2005) A time series approach to inferring groundwater recharge using the water table fluctuation method. Water Resour Res 41:1-9. https://doi.org/10.1029/ 2004WR003077

Crosbie RS, Jolly ID, Leaney FW, Petheram C (2010) Can the dataset of field-based recharge estimates in Australia be used to predict 
recharge in data-poor areas? Hydrol Earth Syst Sci 14:2023-2038. https://doi.org/10.5194/hess-14-2023-2010

Crosbie RS, Dawes WR, Charles SP, Mpelasoka FS, Aryal S, Barron O, Summerell GK (2011) Differences in future recharge estimates due to GCMs, downscaling methods and hydrological models. Geophys Res Lett 38:1-5. https://doi.org/10.1029/2011GL047657

Descroix L, Nouvelot JF, Vauclin M (2002) Evaluation of an antecedent precipitation index to model runoff yield in the western Sierra Madre (North-West Mexico). J Hydrol 263:114-130. https://doi.org/10. 1016/S0022-1694(02)00047-1

Döll P, Fiedler K (2008) Global-scale modeling of groundwater recharge. Hydrol Earth Syst Sci 12:863-885. https://doi.org/10.5194/hess-12863-2008

Epting J, Adrien M, Annette A, Peter H (2021) Climate change effects on groundwater recharge and temperatures in Swiss alluvial aquifers. J Hydrol X 11. https://doi.org/10.1016/j.hydroa.2020.100071

Eshtawi T, Evers M, Tischbein B (2016) Quantifying the impact of urban area expansion on groundwater recharge and surface runoff. Hydrol Sci J 61:826-843. https://doi.org/10.1080/02626667.2014.1000916

Etter S, Addor N, Huss M, Finger D (2017) Climate change impacts on future snow, ice and rain runoff in a Swiss mountain catchment using multi-dataset calibration. J Hydrol Reg Stud 13:222-239. https://doi.org/10.1016/j.ejrh.2017.08.005

Fedora MA, Beschta RL (1989) Storm runoff simulation using an antecedent precipitation index (API) model. J Hydrol 112:121-133. https://doi.org/10.1016/0022-1694(89)90184-4

Feng Y, Burian S, Pomeroy C (2012) A review of impact of ET on Green Infrastructure and urban runoff. In: Proc. of World Environment and Water Resources Congress 2012, pp 197-202. https://doi.org/10. 1061/9780784412312.022

Ficklin DL, Luedeling E, Zhang M (2010) Sensitivity of groundwater recharge under irrigated agriculture to changes in climate, $\mathrm{CO}_{2}$ concentrations and canopy structure. Agric Water Manag 97:10391050. https://doi.org/10.1016/j.agwat.2010.02.009

Fidal J, Kjeldsen TR (2020) Accounting for soil moisture in rainfallrunoff modelling of urban areas. J Hydrol 589. https://doi.org/10. 1016/j.jhydrol.2020.125122

Foster SSD, Chilton PJ (2004) Downstream of downtown: urban wastewater as groundwater recharge. Hydrogeol J 12:115-120. https:// doi.org/10.1007/s10040-003-0296-y

Foster SSD, Morris BL, Chilton PJ (1999) Groundwater in urban development: a review of linkages and concerns. In: Impacts of urban growth on surface water and groundwater quality, Birmingham. IAHS, Wallingford, UK, pp 3-12. https://doi.org/10.1111/j.17456584.2007.00373.x

Fuka DR, Walter MT, Archibald JA, Steenhuis TS Easton ZM (2018) EcoHydRology: A community modeling foundation for EcoHydrology. R package version 0.4.12.1. https://CRAN.Rproject. org $/$ package $=$ EcoHydRology

Gannon JP, Bailey SW, McGuire KJ (2014) Organizing groundwater regimes and response thresholds by soils: a framework for understanding runoff generation in a headwater catchment. Water Resour Res 50:8403-8419. https://doi.org/10.1002/2014WR015498. Received

Gebrehiwot SG, Seibert J, Gärdenäs AI, Mellander PE, Bishop K (2013) Hydrological change detection using modeling: half a century of runoff from four rivers in the Blue Nile Basin. Water Resour Res 49:3842-3851. https://doi.org/10.1002/wrcr.20319

Gremillion P, Gonyeau A, Wanielista M (2000) Application of alternative hydrograph separation models to detect changes in flow paths in a watershed undergoing urban development. Hydrol Process 14: 1485-1501. https://doi.org/10.1002/1099-1085(20000615)14: $8<1485::$ AID-HYP988>3.0.CO;2-1

Griessinger N, Seibert J, Magnusson J, Jonas T (2016) Assessing the benefit of snow data assimilation for runoff modeling in Alpine catchments. Hydrol Earth Syst Sci 20:3895-3905. https://doi.org/ 10.5194/hess-20-3895-2016

Gurdak JJ, Hanson RT, McMahon PB, Bruce BW, McCray JE, Thyne GD, Reedy RC (2007) Climate variability controls on unsaturated water and chemical movement, High Plains aquifer, USA. Vadose Zone J 6:533-547. https://doi.org/10.2136/vzj2006.0087

Hale RL, Turnbull L, Earl S, Grimm N, Riha K, Michalski G, Lohse KA, Childers D (2014) Sources and transport of nitrogen in arid urban watersheds. Environ Sci Technol 48:6211-6219. https://doi.org/10. $1021 / \mathrm{es} 501039 \mathrm{t}$

Harbor JM (1994) A practical method for estimating the impact of landuse change on surface runoff, groundwater recharge and wetland hydrology. J Am Plan Assoc 60:95-108. https://doi.org/10.1080/ 01944369408975555

Healy RW, Cook PG (2002) Using groundwater levels to estimate recharge. Hydrogeol J 10:91-109. https://doi.org/10.1007/s10040001-0178-0

Hernández-Guzmán R, Ruiz-Luna A (2013) SARA: an enhanced curve number-based tool for estimating direct runoff. J Hydroinf 15:881887. https://doi.org/10.2166/hydro.2013.145

Hollender J, Rothardt J, Radny D, Loos M, Epting J, Huggenberger P, Borer P, Singer H (2018) Comprehensive micropollutant screening using LC-HRMS/MS at three riverbank filtration sites to assess natural attenuation and potential implications for human health. Water Res X 1:100007. https://doi.org/10.1016/j.wroa.2018.100007

Hooshyar M, Wang D (2016) An analytical solution of Richards' equation providing the physical basis of SCS curve number method and its proportionality relationship. Water Resour Res 52:6611-6620. https://doi.org/10.1111/j.1752-1688.1969.tb04897.x

Hornero J, Manzano M, Ortega L, Custodio E (2016) Integrating soil water and tracer balances, numerical modelling and GIS tools to estimate regional groundwater recharge: application to the Alcadozo aquifer system (SE Spain). Sci Total Environ 568:415432. https://doi.org/10.1016/j.scitotenv.2016.06.011

Hrachowitz M, Savenije HHG, Blöschl G, McDonnell JJ, Sivapalan M, Pomeroy JW, Arheimer B, Blume T, Clark MP, Ehret U, Fenicia F, Freer JE, Gelfan A, Gupta HV, Hughes DA, Hut RW, Montanari A, Pande S, Tetzlaff D, Troch PA, Uhlenbrook S, Wagener T, Winsemius HC, Woods RA, Zehe E, Cudennec C (2013) A decade of predictions in ungauged basins (PUB): a review. Hydrol Sci J 58: 1198-1255. https://doi.org/10.1080/02626667.2013.803183

Jasechko S, Kirchner JW, Welker JM, McDonnell JJ (2016) Substantial proportion of global streamflow less than three months old. Nat Geosci 9:126-129. https://doi.org/10.1038/ngeo2636

Jurado A, López-Serna R, Vázquez-Suné E, Carrera J, Pujades E, Petrovic M, Barceló D (2014) Occurrence of carbamazepine and five metabolites in an urban aquifer. Chemosphere 115:47-53. https://doi.org/10.1016/j.chemosphere.2014.01.014

K'oreje KO, Vergeynst L, Ombaka D, De Wispelaere P, Okoth M, Van Langenhove H, Demeestere K (2016) Occurrence patterns of pharmaceutical residues in wastewater, surface water and groundwater of Nairobi and Kisumu city, Kenya. Chemosphere 149:238-244. https://doi.org/10.1016/j.chemosphere.2016.01.095

Kirchner JW (2019) Quantifying new water fractions and transit time distributions using ensemble hydrograph separation: theory and benchmark tests. Hydrol Earth Syst Sci 23:303-349. https://doi. org/10.5194/hess-23-303-2019

Klaus J, McDonnell JJ (2013) Hydrograph separation using stable isotopes: review and evaluation. J Hydrol 505:47-64. https://doi.org/ 10.1016/j.jhydrol.2013.09.006

Kohler MA, Linsley MA (1951) Predicting the runoff from storm rainfall. US Dept. Commerce Weather Bureau, Washington, DC, Paper 34

Krejci V, Fankhauser R, Gammeter S, Grottker M, Harmuth B, Merz P, Schilling W (1994) Integriete Siedlungsentwässerung Fallstudie Fehraltorf [Integrated seating system Fallstudie Fehraltorf]. EAWAG, Dübendorf, Switzerland 
Lee KT, Huang JK (2013) Runoff simulation considering time-varying partial contributing area based on current precipitation index. J Hydrol 486:443-454. https://doi.org/10.1016/j.jhydrol.2013.02.016

Lerner DN (1990) Groundwater recharge in urban areas. Atmos Environ, Part B, Urban Atmos 24:29-33. https://doi.org/10.1016/09571272(90)90006-G

Li L, Maier HR, Partington D, Lambert MF, Simmons CT (2014) Performance assessment and improvement of recursive digital baseflow filters for catchments with different physical characteristics and hydrological inputs. Environ Model Softw 54:39-52. https:// doi.org/10.1016/j.envsoft.2013.12.011

Liu G, Schwartz FW, Kim Y (2013) Complex baseflow in urban streams: an example from central Ohio, USA. Environ Earth Sci 70:30053014. https://doi.org/10.1007/s12665-013-2358-3

Lyne VD, Hollick M (1979) Stochastic time-variable rainfall-runoff modelling. Inst. Eng. Aust. National Conference, The Institution of Engineers Australia, Barton, Australia, pp 89-93

Lyon SW, Desilets SLE, Troch PA (2012) A tale of two isotopes: differences in hydrograph separation for a runoff event when using D versus O. Hydrol Process 23:2095-2101. https://doi.org/10.1002/ hyp

Ma T, Li C, Lu Z, Wang B (2014) An effective antecedent precipitation model derived from the power-law relationship between landslide occurrence and rainfall level. Geomorphology 216:187-192. https:// doi.org/10.1016/j.geomorph.2014.03.033

Mdaghri-Alaoui A, Eugster W (2001) Field determination of the water balance of the Areuse River delta, Switzerland. Hydrol Sci J 46: 747-760. https://doi.org/10.1080/02626660109492868

Meriano M, Howard KWF, Eyles N (2011) The role of midsummer urban aquifer recharge in stormflow generation using isotopic and chemical hydrograph separation techniques. J Hydrol 396:82-93. https:// doi.org/10.1016/j.jhydrol.2010.10.041

Meyer JL, Paul MJ, Taulbee WK (2005) Stream ecosystem function in urbanizing landscapes. J North Am Benthol Soc 24:602-612. https://doi.org/10.1899/04-021.1

Michel C, Andréassian V, Perrin C (2005) Soil conservation service curve number method: how to mend a wrong soil moisture accounting procedure? Water Resour Res 41:1-6. https://doi.org/10.1029/ 2004WR003191

Minnig M, Moeck C, Radny D, Schirmer M (2018) Impact of urbanization on groundwater recharge rates in Dübendorf, Switzerland. J Hydrol 563:1135-1146. https://doi.org/10.1016/j.jhydrol.2017.09. 058

Mishra SK, Singh VP (2003) Soil conservation service curve number (SCS-CN) methodology. Water Science and Technology Library, springer, Heidelberg, Germany

Mishra SK, Singh VP, Sansalone JJ, Aravamuthan V (2003) A modified SCS-CN method: characterization and testing. Water Resour Manag 17:37-68. https://doi.org/10.1023/A:1023099005944

Moeck C, Brunner P, Hunkeler D (2016) The influence of model structure on groundwater recharge rates in climate-change impact studies. Hydrogeol J 24:1171-1184. https://doi.org/10.1007/s10040-016$1367-1$

Moeck C, Affolter A, Radny D, Dressmann H, Auckenthaler A, Huggenberger P, Schirmer M (2017) Improved water resource management for a highly complex environment using three-dimensional groundwater modelling. Hydrogeol J. https://doi.org/10.1007/ s10040-017-1640-y

Moeck C, von Freyberg J, Schirmer M (2018) Groundwater recharge predictions in contrasted climate: the effect of model complexity and calibration period on recharge rates. Environ Model Softw 103:74-89. https://doi.org/10.1016/j.envsoft.2018.02.005

Moeck C, Grech-Cumbo N, Podgorski J, Bretzler A, Gurdak JJ, Berg M, Schirmer M (2020a) A global-scale dataset of direct natural groundwater recharge rates: a review of variables, processes and relationships. Sci Total Environ 717:137042. https://doi.org/10. 1016/j.scitotenv.2020.137042

Moeck C, Molson J, Schirmer M (2020b) Pathline density distributions in a null-space Monte Carlo approach to assess groundwater pathways. Groundwater 58:189-207. https://doi.org/10.1111/gwat.12900

Musolff A, Leschik S, Schafmeister MT, ReinstorfF, Strauch G, Krieg R, Schirmer M (2010) Evaluation of xenobiotic impact on urban receiving waters by means of statistical methods. Water Sci Technol 62:684-692. https://doi.org/10.2166/wst.2010.930

Nathan RJ, McMahon TA (1990) Evaluation of automated techniques for base flow and recession analyses. Water Resour Res 26:1465-1473. https://doi.org/10.1029/90wr00136

Orth R, Staudinger M, Seneviratne SI, Seibert J, Zappa M (2015) Does model performance improve with complexity? A case study with three hydrological models. J Hydrol 523:147-159. https://doi.org/ 10.1016/j.jhydrol.2015.01.044

Partington D, Brunner P, Simmons CT, Werner AD, Therrien R, Maier HR, Dandy GC (2012) Evaluation of outputs from automated baseflow separation methods against simulated baseflow from a physically based, surface water-groundwater flow model. J Hydrol 458-459:28-39. https://doi.org/10.1016/j.jhydrol.2012.06.029

Penna D, Tromp-Van Meerveld HJ, Gobbi A, Borga M, Dalla Fontana G (2011) The influence of soil moisture on threshold runoff generation processes in an alpine headwater catchment. Hydrol Earth Syst Sci 15:689-702. https://doi.org/10.5194/hess-15-689-2011

Penna D, van Meerveld HJ, Oliviero O, Zuecco G, Assendelft RS, Dalla Fontana G, Borga M (2015) Seasonal changes in runoff generation in a small forested mountain catchment. Hydrol Process 29:20272042. https://doi.org/10.1002/hyp.10347

Pui A, Lal A, Sharma A (2011) How does the Interdecadal Pacific oscillation affect design floods in Australia? Water Resour Res 47. https://doi.org/10.1029/2010WR009420

Ramgraber M, Weatherl R, Blumensaat F, Schirmer M (2021) NonGaussian parameter inference for hydrogeological models using stein variational gradient descent. Water Resour Res 57. https:// doi.org/10.1029/2020WR029339

Rammal M, Archambeau P, Erpicum S, Orban P, Brouyère S, Pirotton M, Dewals B (2018) Technical note: an operational implementation of recursive digital filter for base flow separation. Water Resour Res 54:8528-8540. https://doi.org/10.1029/2018WR023351

Reinhardt M, Guler A, Schurch M, Sinreich M, Zimmermann S, Kunz M (2019) État et Évolution des Eaux Souterraines en Suisse [State and Evolution of Groundwater in Switzerland]. No. UZ-1901-F, Office fédéral de l'environnement OFE, Bern, Switzerland, $144 \mathrm{pp}$

Rose S, Peters NE (2001) Effects of urbanization on streamflow in the Atlanta area (Georgia, USA): a comparative hydrological approach. Hydrol Process 15:1441-1457. https://doi.org/10.1002/hyp.218

Sahu RK, Mishra SK, Eldho TI (2010) An improved AMC-coupled runoff curve number model. Hydrol Process 24:2834-2839. https://doi.org/10.1002/hyp.7695

Sahu RK, Mishra SK, Eldho TI (2012) Performance evaluation of modified versions of SCS curve number method for two watersheds of Maharashtra, India. ISH J Hydraul Eng 18:27-36. https://doi.org/10. 1080/09715010.2012.662425

Scanlon BR, Healy RW, Cook PG (2002) Choosing appropriate techniques for quantifying groundwater recharge. Hydrogeol J 10:18 39. https://doi.org/10.1007/s10040-001-0176-2

Scanlon BR, Jolly I, Sophocleous M, Zhang L (2007) Global impacts of conversions from natural to agricultural ecosystems on water resources: quantity versus quality. Water Resour Res 43 . https://doi. org/10.1029/2006WR005486

Schirmer M, Reinstorf F, Leschik S, Musolff A, Krieg R, Strauch G, Molson JW, Martienssen M, Schirmer K (2011) Mass fluxes of xenobiotics below cities: challenges in urban hydrogeology. Environ Earth Sci 64:607-617. https://doi.org/10.1007/s12665010-0880-0 
Schirmer M, Leschik S, Musolff A (2013) Current research in urban hydrogeology: a review. Adv Water Resour 51:280-291. https:// doi.org/10.1016/j.advwatres.2012.06.015

Seibert J (1999) Regionalisation of parameters for a conceptual rainfallrunoff model. Agric For Meteorol 98-99:279-293. https://doi.org/ 10.1016/S0168-1923(99)00105-7

Seibert J, Vis MJP (2012) Teaching hydrological modeling with a userfriendly catchment-runoff-model software package. Hydrol Earth Syst Sci 16:3315-3325. https://doi.org/10.5194/hess-16-3315-2012

Sharp JM (2010) The impacts of urbanization on groundwater systems and recharge. Aquamundi 1:51-56

Sharp JM, Krothe JN, Mather JD, Gracia-Fresca B, Stewart CA (2003) Effects of urbanization on groundwater systems. In: Heiken G, Fakundiny R, Sutter J (eds) Earth science in the city: a reader. https://doi.org/10.1029/SP056p0257

Sheffield J, Wood EF, Pan M, Beck H, Coccia G, Serrat-Capdevila A, Verbist K (2018) Satellite remote sensing for water resources management: potential for supporting sustainable development in datapoor regions. Water Resour Res 54:9724-9758. https://doi.org/10. 1029/2017WR022437

Singh PK, Mishra SK, Berndtsson R, Jain MK, Pandey RP (2015) Development of a modified SMA based MSCS-CN model for runoff estimation. Water Resour Manag 29:4111-4127. https://doi.org/ 10.1007/s11269-015-1048-1

Solomon DK, Schiff SL, Poreda RJ, Clarke WB (1993) A validation of the $3 \mathrm{H} / 3 \mathrm{He}$ method for determining groundwater recharge. Water Resour Res 29:2951-2962. https://doi.org/10.1029/93WR00968

Soulis KX, Valiantzas JD (2012) SCS-CN parameter determination using rainfall-runoff data in heterogeneous watersheds: the two-CN system approach. Hydrol Earth Syst Sci 16:1001-1015. https://doi.org/ 10.5194/hess-16-1001-2012

Stanton JS, Ryter DW, Peterson SM (2013) Effects of linking a soilwater-balance model with a groundwater-flow model. Groundwater 51:613-622. https://doi.org/10.1111/j.1745-6584. 2012.01000.x

Stoll S, Hendricks Franssen HJ, Butts M, Kinzelbach W (2011) Analysis of the impact of climate change on groundwater related hydrological fluxes: a multi-model approach including different downscaling methods. Hydrol Earth Syst Sci 15:21-38. https://doi.org/10.5194/ hess-15-21-2011

Thomas A, Tellam J (2006) Modelling of recharge and pollutant fluxes to urban groundwaters. Sci Total Environ 360:158-179. https://doi. org/10.1016/j.scitotenv.2005.08.050

Thomas BF, Famiglietti JS, Landerer FW, Wiese DN, Molotch NP, Argus DF (2017) GRACE groundwater drought index: evaluation of California Central Valley groundwater drought. Remote Sens Environ 198:384-392. https://doi.org/10.1016/j.rse.2017.06.026

Tweed SO, Leblanc M, Webb JA, Lubczynski MW (2007) Remote sensing and GIS for mapping groundwater recharge and discharge areas in salinity prone catchments, southeastern Australia. Hydrogeol J 15:75-96. https://doi.org/10.1007/s10040-006-0129-x

USDA Natural Resources Conservation Service (1986) Urban hydrology for small watersheds. Technical Release 55, USDA Natural Resources Conservation Service, Washington, DC

Van Dijk AIJM, Gash JH, Van Gorsel E, Blanken PD, Cescatti A, Emmel C, Gielen B, Harman IN, Kiely G, Merbold L, Montagnani L, Moors E, Sottocornola M, Varlagin A, Williams CA, Wohlfahrt G
(2015) Rainfall interception and the coupled surface water and energy balance. Agric For Meteorol 214-215:402-415. https://doi.org/ 10.1016/j.agrformet.2015.09.006

Vázquez-Suñé E, Sánchez-Vila X, Carrera J (2005) Introductory review of specific factors influencing urban groundwater, an emerging branch of hydrogeology, with reference to Barcelona, Spain. Hydrogeol J 13:522-533. https://doi.org/10.1007/s10040-0040360-2

Verma S, Verma RK, Mishra SK, Singh A, Jayaraj GK (2017) A revisit of NRCS-CN inspired models coupled with RS and GIS for runoff estimation. Hydrol Sci J 62:1891-1930. https://doi.org/10.1080/ 02626667.2017 .1334166

Vogt JV, Somma F (2000) DDrought and Drought Mitigation in Europe. Kluwer Academic Publishers, Dordrecht/Boston/London. 336 pgs.

von Freyberg J, Moeck C, Schirmer M (2015) Estimation of groundwater recharge and drought severity with varying model complexity. J Hydrol 527:844-857. https://doi.org/10.1016/j.jhydrol.2015.05.025

von Freyberg J, Studer B, Kirchner JW (2017) A lab in the field: highfrequency analysis of water quality and stable isotopes in stream water and precipitation. Hydrol Earth Syst Sci 21:1721-1739. https://doi.org/10.5194/hess-21-1721-2017

von Freyberg J, Studer B, Rinderer M, Kirchner JW (2018) Studying catchment storm response using event and pre-event water volumes as fractions of precipitation rather than discharge. Hydrol Earth Syst Sci 22. https://doi.org/10.5194/hess-22-5847-2018

Wakode HB, Baier K, Jha R, Azzam R (2018) Impact of urbanization on groundwater recharge and urban water balance for the city of Hyderabad, India. Int Soil Water Conserv Res 6:51-62. https://doi. org/10.1016/j.iswcr.2017.10.003

Wał ga A, Rutkowska A (2015) Usefulness of the modified NRCS-CN method for the assessment of direct runoff in a mountain catchment. Acta Geophys 63:1423-1446. https://doi.org/10.1515/acgeo-20150043

Wang X, Liu T, Yang W (2012) Development of a robust runoffprediction model by fusing the rational equation and a modified SCS-CN method. Hydrol Sci J 57:1118-1140. https://doi.org/10. 1080/02626667.2012.701305

Willems P (2009) A time series tool to support the multi-criteria performance evaluation of rainfall-runoff models. Environ Model Softw 24:311-321. https://doi.org/10.1016/j.envsoft.2008.09.005

Wittenberg H, Sivapalan M (1999) Watershed groundwater balance estimation using streamflow recession analysis and baseflow separation. J Hydrol 219:20-33. https://doi.org/10.1016/S0022-1694(99) 00040-2

Woldemeskel F, Sharma A (2016) Should flood regimes change in a warming climate? The role of antecedent moisture conditions. Geophys Res Lett 43:7556-7563. https://doi.org/10.1002/ 2016GL069448

Zope PE, Eldho TI, Jothiprakash V (2017) Hydrological impacts of land use-land cover change and detention basins on urban flood hazard: a case study of Poisar River basin, Mumbai, India. Nat Hazards 87: 1267-1283. https://doi.org/10.1007/s11069-017-2816-4

Publisher's note Springer Nature remains neutral with regard to jurisdictional claims in published maps and institutional affiliations. 